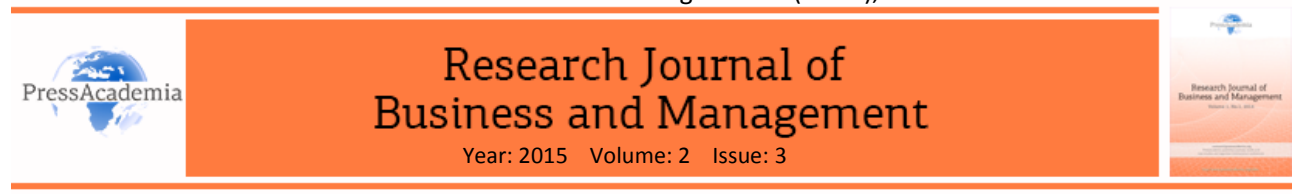

\title{
THE ROLE OF PSYCHOLOGICAL EMPOWERMENT ON THE RELATIONSHIP BETWEEN PERSONALITY AND JOB SATISFACTION
}

\section{DOI: 10.17261/Pressacademia.2015312979}

\author{
Ceren Aydogmus', Azize Ergeneli², Selin Metin Camgoz ${ }^{3}$ \\ 'Bilkent University. caydogmus@bilkent.edu.tr \\ ${ }^{2}$ Hacettepe University. ergeneli@hacettepe.edu.tr \\ ${ }^{3}$ Hacettepe University. selinm@hacettepe.edu.tr
}

\author{
Keywords \\ Personality, \\ conscientiousness, \\ neuroticism, \\ psychological \\ empowerment, \\ job satisfaction.
}

\section{JEL Classification} M10, M12

\begin{abstract}
This study proposes a model for the impact of the employees' psychological empowerment on the relationship between their personality characteristics and job satisfaction. The model was tested on a sample of 221 participants working in education and IT sectors. For the indicators of participants' personality, Big Five Model, involving extraversion, conscientiousness, agreeableness, openness to experience and neuroticsm traits, has been applied in the study. Findings reveal that psychological empowerment positively influence job satisfaction. Conscientiousness, openness to experience and neuroticism are found to be the predictors of job satisfaction. As a result of the regression analyses, psychological empowerment is revealed as the mediating mechanism on personality and job satisfaction relationship. More specifically, followers' psychological empowerment, including competence, impact, meaning and self-determination, partially mediated the effect of followers' conscientiousness on job satisfaction and fully mediated neuroticism and job satisfaction relationship. The findings are discussed along with some theoretical and practical implications.
\end{abstract}

\section{KişiLiK iLE iş TATMINi iLişKISi ÜZERINDE PSiKOLOJiK GÜÇLENDIRMENIN ROLÜ}

\section{Anahtar Kelimeler}

Kişilik, Sorumluluk, Nevrotizm, Psikolojik güçlendirme, İş tatmini.

\section{JEL Sınıflandırması} M10, M12

\section{ÖZET}

Bu araştırma, çalışanların kişilik özellikleri ile iş tatminleri ilişkisi üzerinde psikolojik güçlendirme algısının etkisini inceleyen bir model sunmaktadır. Modelin örneklemini eğitim ve bilişim sektöründe çalışmakta olan 221 katılımcı oluşturmaktadır. Çalışmada kişilik özelliklerini tespit etmek için dışa dönüklük, sorumluluk, uyumluluk, deneyimlere açıkıı ve nevrotizm özelliklerinin yer aldığı Beş Faktör Modeli kullanılmıştır. Elde edilen bulgular psikolojik güçlendirmenin iş tatminini pozitif yönde etkilediğini göstermektedir. Kişilik özellikleri içerisinde sorumluluk, deneyimlere açıklık ve nevrotizm iş tatminini belirleyen özellikler olarak bulunmuştur. Çalışmada, psikolojik güçlendirme, kişilik ve iş tatmini ilişkisinde aracı değişken olarak tespit edilmiştir. Yapılan regresyon analizleri neticesinde, yetkinlik, etki, anlam ve özerklik boyutlarından oluşan psikolojik güçlendirmenin çalışanların sorumluluğu ile iş tatminleri arasında kısmi aracılık, nevrotizm ile iş tatmini arasında ise tam aracılık etkisine sahip olduğu belirlenmiştir. Bulgular kuramsal önemi ve pratik uygulamaları açısından tartışılmaktadır. 


\section{GíRiş}

Örgütlerin artan rekabet, teknolojik gelişmeler ve küreselleşme neticesinde sürekli değişen günümüz koşullarında varlıklarını sürdürmeleri ve gelişebilmeleri için yüksek iş tatminine sahip çalışanlara sahip olması hayati önem taşımaktadır. İş tatmini çalışanın motivasyonunu, performansını ve örgüte olan bağııı̆ı̆ını arttırması sebebiyle en önemli iş tutumu olarak değerlendirilmektedir (Ergeneli, 2006). Bireyin işine karşı olan tutumu olumlu olduğunda, tatmin olduğu, olumsuz olduğunda ise tatminsizliği ifade etmektedir. İşteki tatminsizlik ise, işe devamsızlığı ve işten ayrılma oranlarını arttırmaktadır (Aydogdu ve Asıkgil, 2011; Ergeneli, 2006). Öte yandan, çalıştıkları iş yerlerinde motive olmuş ve iş tatminine sahip olan kişiler, yüksek morale de sahip olurlar. Bunun neticesinde çalışanların iş yerlerine olan faydaları da artar (Schoderbek vd., 1991). İş tatmini örgütsel psikoloji ve davranış alanında en fazla çalışılan konuların başında gelmektedir (Judge vd., 2001). İş tatminini oluşturan unsurlar genel olarak iş özellikleri, rol çatışması ve belirsizliği, algılanan örgütsel destek ve adalet (Kim ve Leung, 2007) gibi durumsal faktörlere odaklanmıştır. Öte yandan, iş tatmininin yaradılışdan gelen özelliklerden de kaynaklandığı kanıtlanmıştır (Judge ve Larsen, 2001; Özgen vd., 2002). Kişilik, bireyin iş seçimini, çevresindekilerle ilişkisini, iş arkadaşlarına ve amirine karşı olan davranışını, ödül ve ceza süreçlerine karşı olan tutumunu belirleyen duygu, düşünce ve davranış kalıplarını oluşturmaktadır. Özellikle son yıllarda, iş tatmininin kişilik özellikleri ile olan ilişkisini inceleyen (Furnham vd., 2002; Karatepe vd., 2006; Templer, 2012; Winkelmann ve Winkelmann, 2008) ve bireysel farlılıklara neden olan özelliklerin tespit edilmesine dair çeşitli araştırmalar mevcuttur (Judge ve Larsen, 2001; Motowidlo, 1996). Ancak, çalışanın kişilik özelliklerinin iş tatminini hangi mekanizmalar vasıtasıyla etkilediğine ilişkin az sayıda çalışma bulunmaktadır (Judge ve Larsen, 2001; Judge vd., 2000). Buradan hareketle, bu çalışmanın amacı, kişilik özelliklerinin bireyin iş tatminini nasıl etkilediği sorusuna cevap aramaktır.

Kişilik özellikleri, bireylerin iş koşullarını nasıl algıladıklarını, duygusal ve davranışsal olarak verdikleri tepkileri etkilemektedir. Bu bağlamda, kişinin algısı önem kazanmaktadır (Templer, 2012). Bu noktada, çalışanın bireysel algısı ile doğrudan ilişkili olan psikolojik güçlendirme olgusu devreye girmektedir. Güçlendirmenin bilişsel olarak değerlendirildiği psikolojik güçlendirme yaklaşımında, güçlendirmenin gerçekleşebilmesi için, üst yönetimin neler yapması gerektiğine değil, yapılanların çalışanlar tarafından nasıl algılandı̆̆ı̈zerinde durulmaktadır (Spreitzer, 1995). Yönetsel birtakım uygulamalar kişiler tarafından farklı şekilde algılanabilmektedir. Çalışanların mevcut iş koşullarına dair olan algıları, değerleri ve bu değerlerin iş yaşamında karşılanması ise onların iş tatminini oluşturur. Çalışanın temel gereksinimleri doğuştandır, oysa değerleri kazanılmıştır. Gereksinimler, çalışanı eyleme geçirirler, ancak ortaya çıkacak duygusal tepkileri ve seçimleri, çalışanın değerleri kararlaştırır. Tüm insanlar aynı temel gereksinimlere sahiptirler, ancak değer verdikleri olaylar birbirinden farklıdır. Diğer taraftan, çalışanın beklentileri ile değerleri arasında paralellik vardır. Çalışanın bir olayı yüksek düzeyde beklemesi, ona büyük değer vermesindendir, çünkü beklentiler, değerlerin doğmasına neden olmaktadır (Locke, 1976). $\mathrm{Bu}$ anlayışla, çalışan, değer verdiği olguların tamamen karşılandığını düşünüyor ise, iş tatmini de doğal olarak artacaktır (Spreitzer vd., 1997). Psikolojik güçlendirme ile iş tatmini arasındaki ilişki ile ilgili daha fazla güçlendirme hisseden çalışanların, çalışmak için daha çok motive olduğuna ilişkin gerek Türk yazınında (Çalışkan ve Hazır, 2012; Tolay vd., 2012; 
Yürür ve Demir, 2011), gerekse de uluslararası yazında (Chen vd., 2007; Liden vd., 2000; Spreitzer, 2007) çeşitli araştırmalar yapılmış olmasına rağmen, insan yaradılışının güçlendirme algısını etkilemesi ile ilgili olarak çok az araştırma (Aydogmus, 2011) yapılmıştır. Çalışanın kişilik özellikleri güçlendirmeyi şekillendirmekte ve neticede çalışan davranışını motive etmektedir. Kişinin yaradılışı, psikolojik güçlendirmeyi tahmin edebilmekte ya da psikolojik güçlendirme algısı üzerinde aracılık etkisi gösterebilmektedir (Spreitzer, 1995). Bu noktadan hareketle, bu araştırmada çalışanların kişilik özellikleri ile iş tatminleri arasındaki ilişkiler üzerinde psikolojik güçlendirmenin aracılık etkisi incelenecektir.

\section{LITERATÜR}

\subsection{Kişilik Özellikleri ve İş Tatmini}

Çalışma hayatına atılan bir insan, ilk olarak kendi kişilik yapısıyla örgüt içinde yerini alır. Kendi kişilik yapısıyla yapacağı iş ve içinde yer aldığı örgüt uyum içinde olduğu takdirde bireyin iş yaşamındaki başarısı yükselir. Aksi halde işin sonucunda bireyin beklentisi yerine getirilememiş olur (Tınar, 1999). Ayrıca, bireyin içinde yer aldığı sosyal yapı ile kişiliği arasında bir bağ kurulacak olursa birey, grup normlarına uymada güçlük çekmeyecek ve davranışları ile grup üyeleriyle ilişkileri arasında yönetsel etkinliği artıracak bir ilişki kurulacaktır. Kişinin beklentisi ile örgütün amaçları arasında istenen bağın kurulması örgütün devamlılığı açısından da son derece önemlidir. Bu da büyük ölçüde çalışanların kişiliğine bağııdır (Aydogmus, 2011).

Kişilik özelliklerinin ölçülmesinde temel paradigma olarak Beş Faktör Modeli'ndeki özellikler toplam 56 farklı kültürde genel kabul görmüş durumdadır (Schmitt vd., 2007). Somer ve Goldberg (1999) Türkçe sözlükteki kişilik özelliklerini tanımlayan sıfatlarla ilgili yaptıkları araştırmada Beş Faktör Modeli'ni destekleyici bulgulara ulaşmışlardır. Modelin yapısal özellikleri ülkemizde de desteklenmiş durumdadır ve bu araştırmada da çalışan ve yöneticilerin kişilik özellikleri ölçümünde geçerlilik ve güvenilirliği kanıtlanmış 5 Faktör Modeli kullanılacaktır. Yapılan araştırmalar bu modelin insan kişiliğindeki önemli farklılıklarının hemen hemen büyük bir bölümünü içerdiğini ortaya koymuştur (Can vd., 2006). Türk yazınında pek çok araştırma, kişilik özelliklerini Beş Faktör Modeli çerçevesinde ele almaktadır (Basım vd., 2009; Tabak vd. 2010). Beş Faktör Modeli'nde yer alan kişilik özellikleri birbirine zıt iki ayrı kutuptan oluşan beş ayrı kişilik boyutunu kapsamaktadır. Bu boyutlar sırasıyla: dışa dönüklük/içe dönüklük, uyumluluk/uyumsuzluk, sorumluluk/hedefsizlik, duygusal dengesizlik (nevrotizm)/duygusal denge, deneyimlere açıklık/deneyimlere kapalı olmaktır (Costa ve McCrae, 1992). Özellikle son yıllarda bu beş özellik, firmalarda eleman seçimi ve değerlendirilmesinde de kullanılmaya başlanmıştır (Salgado ve De Fruyt, 2005).

Çalışanların kişilik özelliklerinin, iş tatminlerini etkilediği konusu özellikle son yıllarda önemli bir araştırma konusu olmuştur (Judge vd., 2008). İş tatmini çalışanın işinden istediği ile elde ettiğini karşılaştırması sonucunda göstermiş olduğu duygusal tepkidir (Samad, 2006). İş tatmini ve Beş Faktör Modeli arasında doğal bir ilişki mevcuttur. Kişiliklerine uygun işlerde çalışanlar, uygun olmayan işlerde çalışanlara göre daha başarılı ve daha mutludurlar (Holland, 1985). 
Dışa dönüklük kişilik özelliği, bireylerin ilişkilerindeki rahatlık derecesini gösteren boyuttur. Dışa dönük kişiler düzenli ve toplu olmayı seven, iddiacı ve başkalarıyla birlikte bulunmaktan hoşlanan kişilerdir (Judge ve Bono, 2000). Dışa dönüklük, kişinin sosyal etkileşimlerinde ne derecede katılımcı ve enerjik olduğunu ölçer. Yüksek puan, kişinin sosyal ilişkilere oldukça zaman ayırdığını, hareketli ve canlı biri olduğunu gösterir. Dışa dönüklük puanı düşük olan kişiler ise içe dönüklerdir. Düşük puan, kişinin zamanının çoğunu kendi başına geçirdiğini ve az hareketli bir yaşam tarzını tercih ettiğini gösterir. Bu tarz kişilerin çevresindekilerle olan ilişkileri uzak ve resmidir. Genel olarak tek başına olmayı tercih eder ve sosyal ortamlarda geri planda kalırlar. Acelesiz ve yavaş davranan bir yapıları vardır (Watson ve Clark, 1997). Memnuniyet verici birtakım olaylarla karşılaşıldığında, dışa dönükler, içe dönük kişilere kıyasla daha pozitif reaksiyonlar deneyimlerler (Rusting ve Larsen, 1997). Bu tarz kişilerin iş tatmini ile neticelenen daha olumlu hissetme eğilimleri vardır (Costa ve McCrae, 1992). Olumlu değerlendirmelerle çevrelerini irdeleyen dışa dönükler yaptıkları işleri daha ilgi çekici bulur ve kendilerine verilen görevleri olumlu bir şekilde yorumlarlar (Judge vd., 2000). Dışa dönüklük, iş tatmini ile doğrudan ilişkili olumlu duygulanımı temsil etmektedir (Brief , 1998; Connolly and Viswesvaran, 2000; Judge vd., 2002). Aynı zamanda dışa dönüklerin sosyal olmalarından dolayı, içe dönük kişilere kıyasla daha fazla sayıda arkadaşları olmakta ve iş yerlerinde kişilerarası ilişkilerden daha fazla fayda sağlamaktadırlar (Watson ve Clark, 1997).

Sorumluluk boyutu ise kişinin hedeflere nasıl odaklandığını ölçmektedir. Hem çalışkan ve hırslı olmayı, hem de düzenli, planlı, programlı ve görevine düşkün olmayı içermektedir (McCrae ve Costa, 1989). Beş Faktör Modeli içinde iş performansı ile en fazla ilişkiye sahip olan kişilik özelliğidir. İş ve görev merkezli olmayı, yaptığı işe kendini vermeyi, kendine verilen görevi en iyi şekilde yapmak gayretinde olmayı ifade etmektedir. Sorumluluğun, iş psikolojisinde yapılan araştırmalarda, çalışanlarda bulunması en çok arzu edilen özellik olduğu tespit edilmiştir (Barrick vd., 2001). Sorumluluk boyutunda yüksek puan, belirli hedeflere oldukça disiplinli bir şekilde odaklanmayı, belli bir amacı gerçekleştirmek için sistemli ve ısrarlı çalışmayı gösterir. Bu tarz kişiler, hedeflerine ulaşmak için sabırla çalışırlar. Yüksek puan alanlar sorumlu, düzenli, kişisel disipline sahip, organize, planlı ve dikkatli kişilerdir. Düşük puan (hedefsizlik) ise çok sayıda hedefi kesik kesik ve değişken bir odaklanma ile takip etmeyi gösterir. Düşük puana sahip olanlar düzensiz, sorumluluk düzeyleri az ve hedeflerinden kolayca şaşabilen kişilerdir (Costa ve McCrae, 1992). Yüksek derecede performans gösteren bireylerin, iş yerlerinde daha fazla kabul görecekleri ve ödül alacakları sebebiyle sorumluluk iş tatminini etkileyen en önemli kişilik özelliği olarak belirlenmiştir (Raja ve Johns, 2004). Bu tarz çalışanların iş tatminleri en yüksek düzeyde olacaktır (Judge vd., 2001). Sorumluluğun iş tatminini olumlu olarak etkilediği pekçok araştırmada kanıtlanmış bulunmaktadır (DeNeve ve Cooper, 1998; Judge vd., 2002; Templer, 2012; Winkelman ve Winkelman, 2008).

Uyumluluk, kişinin davranışlarında çevresine yönelik güven ve duyarlılı̆ını ve çevresel kriterlerle içsel kriterleri hangi oranda kullandığını ölçmektedir. Bu boyut nazik, anlayışı, hoşgörülü, şevkatli, yumuşak başı, güvenilir, mert, samimi ve ılımlı olma eğilimini içerir (Judge ve Bono, 2000). Uyumluluk boyutunda yüksek puan, kişinin, çevresine güven duyan, çevresindeki kişilerin intiyaçlarını karşılayan ve içinde bulunduğu grubun normlarına yüksek derecede bağlı kalan biri olduğunu gösterir. Uyumlu kişiler aynı zamanda 
çevresindeki kişilere karşı saygılı, nazik, ince, açık kalpli ve merhametlidirler (Costa vd., 1991). Yüksek uyumlu kişiler, işbirliği içinde olan, iyi huylu, tolerasanlı, anlayışlı, sıcak ve güvenilir bireylerdir (Digman, 1990). Bu tarz kişiler yakın ve samimi ilişkilere değer verir, çatışmadan kaçınırlar. Uyumlulukta düşük puan ise (uyumsuzluk), kişinin yönlendirici ve baskılayıcı biri olduğunu ve kendini ön plana çıkarma eğiliminde olduğunu gösterir. Bu tarz kişilerin rekabetçi, inatçı, kin güden, alıngan, dik kafalı ve hırçın bir yapıları vardır. Bu kişilerin çevresindekilerle olan ilişkileri yüksek düzeyde çatışma içerir. Uyumluluk puanı düşük olanlar soğuk, geçimsiz ve muhalif kişilerdir (Graziano ve Eisenberg, 1997). İş arkadaşları ile uyumlu ilişkilerinden dolayı, uyumluluk puanı yüksek olan kişilerin ise iş tatminlerinin fazla olacağı belirtilmektedir (Organ ve Ryan, 1995). Ayrıca, uyumlu çalışanların kişilerarası ilişkilerde daha fazla motive oldukları belirlenmiştir (McCrae ve Costa, 1991). Acuna ve diğerleri (2009) ise uyumlu çalışanlara sahip grupların iş tatmini seviyelerinin yüksek olduğunu kanıtlamıştır. Buna karşılık, uyumluluğun iş tatmini üzerindeki etkisinin sorumluluk, dışa dönüklük (pozitif yönde) ve nevrotizm (negatif yönde) kadar güçlü çıkmadığı tespit edilmiştir (Winkelman ve Winkelman, 2008). Ayrıca, Judge ve diğerleri (2002) çalışmalarında, uyumluluk özelliğinin iş tatminini belirlemede anlamlı bir değişken olmadığını göstermişlerdir

Deneyimlere açıklık kişilik özelliği bireyin entellektüel ve kültürel alanlara ilgi ve değişimlere açıklık derecesini ölçer. Inssanların ilgilerinin genişliğini ve yeniliklerden etkilenme derecesini ifade etmektedir. Bu kişilik faktörü analitik, karmaşık, bağımsız, yaratıcı, liberal, orijinal, cesur, değişik fikirleri seven, artistik, açık fikirli gibi sıfatlarla ilişkilendirilmiştir (Somer vd., 2001). Deneyimlere açık olma boyutunda yüksek puan, zengin bir fikir ve hayal dünyasını, çok sayıda alana ilgi duymayı, yeniliğe ve değişime açık olmayı gösterir. Düşük puan ise, hayatın daha somut ve uygulamaya dönük yönleriyle ilgili olmayı, bilinen yöntemlere bağlı kalmayı ve değişim karşısında dirençli olmayı göstermektedir. Deneyimlere kapalı kişiler, klasik olan ve bilinenden rahatlık duyan bireylerdir (Can vd., 2006). Bu tarz kişiler muhafazakar ve şüphecidirler. Olağan durumda kalmak isterler, değişikliklerden hoşlanmazlar. Belirsizliği azalttığı için alışıldık ve geleneksel olan görevleri tercih ederler (Choi, 2004). Yaratıcılık bireysel performansa etki eden önemli belirleyicilerdendir. Kişilik - tatmin ilişkisi bireylerin yaratıcı performanslarını açıklayan bir faktör olarak belirtilmiş ve deneyimlere açıklık ile yaratıcı performans açısından belirgin pozitif yönde ilişki bulunmuştur (Sun ve Jin, 2009). Bireyin merakı, yeterlilik ve gelişme duygusu, büyüme ve yarışma duygusu gibi ihtiyaçlar içsel iş tatmini kaynaklarıdır. Dışsal iş tatminine ise bir görevin ya da etkinliğin tamamlanması için sağlanan ödüller neden olabilmektedir. Deneyimlere açıklık ile yaratıcı performans arasındaki pozitif ilişki çalışanda dışsal iş tatmini olduğunda daha fazla kuvvetlenmektedir. İçsel iş tatmini ise yaratıcılığa etki eden faktörlerden biri değildir. Uyumluluk ise kişinin dışsal iş tatmini düşük olduğunda, yaratıcı performansın pozitif belirleyicilerindendir. Genel olarak ödül gibi dışsal motivasyon kaynaklarının yaratıcılığı arttırdığı gözlemlenmiştir (Choi, 2004). Ayrıca, deneyimlere açıklık ile iş tatmini arasında ilişki olmadığını gösteren çalışmalar (Judge vd., 2002) da mevcuttur.

Son olarak, duygusal denge, kişinin strese dayanıklılık ölçüsüdür. Kişinin dışsal olaylardan etkilenmeye ne derecede açık olduğunu ölçer ve kişinin sakinliğinin ölçümüdür (Barrick ve Mount, 1991). Duygusal denge puanı yüksek olan bireyler sakin, olumlu, geleceğe dair 
umutlu, kendilerine güvenen, öz saygıları yüksek ve sinirlendiklerinde bile sakin kalmayı başarabilen kişilerdir. Öte yandan duygusal denge puanı düşük, diğer bir deyişle nevrotik kişiler düşüncesiz, endişeli, kaygılı, utangaç, huzursuz, tedirgin, sinirli, karamsar, kaprisli ve umutsuz bireylerdir. Kişi dışsal olaylardan daha çok etkilenme ve bunlara tepki gösterme eğilimindedir. Ayrıca, bu tarz kişilerin kendilerine güvenleri ve öz saygıları çok azdır. Duygusal dengesizliğe sahip olan (nevrotik) kişiler depresyona ve diğer ruhsal rahatsızlıklara sahip olabilen bireylerdir (McCrae ve Costa, 1991). Nevrotizm negatif duygulanım olarak ifade edilmekte (Brief, 1998) ve iş tatminsizliğine sebep olmaktadır (Moyle, 1995). Duygusal denge, kişinin hem iş, hem de hayattan tatmin sağlama konusunda önemli bir etkiye sahiptir. Nevrotizm ise neticede iş tatminini negatif yönde etkilemektedir (Judge vd., 2008; Tanoff ve Oregon, 1999; Winkelmann ve Winkelmann, 2008).

Türk yazını değerlendirildiğinde ise iş tatmini etkileyen etmenler ile ilgili birçok çalışma olmasına rağmen (Çekmecelioğlu, 2005; Gürbüz ve Yüksel, 2008; Toker, 2007) çalışan kişiliğinin iş tatminine olan etkisi ile ilgili çok fazla sayıda araştırma (Aydogmus, 2011) bulunmamaktadır. Bu çalışmanın, örgütlerde çok büyük önem taşıyan iş tatmininin psikolojik yönünün anlaşılmasında Türk yazınına katkıda bulunacak nitelikte olduğu düşünülmektedir.

\subsection{Kişilik Özellikleri-iş Tatmini ílişkisi Üzerinde Psikolojik Güçlendirmenin Etkisi}

Çalışan kişiliği ile iş tatmini ilişkisi ile ilgili olarak çeşitli araştırmalar bulunsa da, söz konusu ilişki üzerinde çalışanın güçlendirme algısının araclılık etkisine ilişkin gerek Türk yazınında, gerekse de uluslarası yazında araştırma yapılmadığı görülmüştür (Aydogmus, 2011). Psikolojk güçlendirme (Spreitzer, 1995) ile kişilik ilişkisi, iş tatminini belirleme açısından ele alınmış olsa da (Manojlovich vd., 2002), beş faktör kişilik özellikleri ile olan bağlantısı değerlendirilmemiştir.

Çalışanları etkileyen en önemli faktörlerden biri güçlendirme olgusudur. Artan rekabet ve hızla değişen çevresel şartlar sonucu önemli fırsat ve tehditlerle karşı karşıya kalan örgütler, çalışanlarından maksimum fayda sağlayabilmek amacıyla, onları işleri ve iş yerleriyle bütünleştirmek suretiyle güçlendirmektedir. Güçlendirme, güçsüzlüğe etki eden faktörlerin tanımlanması, bunların gerek biçimsel örgüt uygulamaları, gerekse etkili bilgilendirmeyi sağlayacak biçimsel olmayan örgütsel uygulamalar yoluyla, örgüt üyelerinin öz yeterlik duygularını arttırma süreci olarak tanımlanabilir (Conger ve Kanungo, 1988). Bir başka açıdan güçlendirme, çalışanlara kendi kararlarını verme ya da kendi eylemlerinin sorumluluklarını alma olanağı vermektedir (Erstad, 1997). Son 20 yılda, literatürde iş yerlerindeki güçlendirme ile ilgili birbirini tamamlayan iki yaklaşım geliştirilmiştir (Liden ve Arad, 1996). Bu yaklaşımlardan ilki daha makro bir bakış açısına sahip olan ve iş yerlerindeki sosyo-yapısal durumlara odaklanan güçlendirme tipidir. Diğeri ise daha çok mikro bir bakış açısına sahip olup, iş yerlerindeki çalışanların güçlendirme algıları ya da kendilerinin güçlendirildiklerine ilişkin algılarına odaklanmaktadır (Liden ve Arad, 1996). Güçlendirmenin makro ve mikro bakış açıları aynı zamanda "davranışsal" ve "bilişsel" açıdan da değerlendirilebilir. Güçlendirmenin davranışsal boyutta ele alındığı çalışmaların odak noktasını, yöneticilerin, çalışanları güçlendirmedeki rolü oluşturmaktadır (Honold, 
1997). Güçlendirmeyi bilişsel boyutta ele alan yazarlar ise, bu olguyu "psikolojik" açıdan ele almakta ve işgörenlerin algılamaları üzerine odaklanmaktadırlar (Conger ve Kanungo, 1988; Spreitzer, 1995). Bu bakış açısında, güçlendirmenin temelde, bireylerin kendi varlıkları ve algılamaları ile ilgili olduğunu, dolayısıyla bu çerçevede üst yönetimin güçlendirmeye dönük davranışlarının ya da oluşturduğu çalışma koşullarının tek başına yeterli olmadığı belirtilmektedir (Thomas ve Velthouse, 1990). Güçlendirmenin bilişsel olarak değerlendirildiği psikolojik güçlendirme yaklaşımında, güçlendirmenin gerçekleşebilmesi için, üst yönetimin neler yapması gerektiğine değil, yapılanların çalışanlar tarafından nasıl algılandığı üzerinde durulmaktadır. Psikolojik güçlendirme, bireyin işte takındığı role karşı eğilimini etkileyerek kişinin içsel görev motivasyonunu arttıran anlam, yetkinlik, özerklik ve etki olmak üzere dört temel bilişsel kavramdan oluşan bir bütündür (Thomas ve Velthouse, 1990). Anlam, çalışanın kişisel değerleri ve standartları ile işe ilişkin amaç ve hedefleri karşılaştırarak bir sonuç çıkarmasıdır. Bu sonuç, işin birey için taşıdığı değerdir. İş ile ilgili amaç ve hedefler ile çalışanın kişisel değerleri ve standartları birbirine yaklaştıkça, işin birey için taşıdığı önem de artacaktır (Thomas ve Velthouse, 1990). Yetkinlik, bireyin, işi en iyi şekilde yapabileceği yönünde kendi yeteneklerine olan inancıdır. Diğer bir ifadeyle, bireyin işini ve iş ortamını şekillendirmek istemesi ve buna yetisinin olmasıdır. Özerklik, çalışan kişinin işini istediği gibi düzene sokması, ayrıca işi ile ilgili işlemleri yapmaya başlama kararını kendi başına verebilmesidir. Çalışan, kararları kendisi alınca, aynı zamanda iş çevresini de kontrol edebildiği duygusuna sahip olmaktadır. Son olarak etki ise bireyin, iş ile ilgili stratejik, yönetsel ve işlemsel çıktıları etkileyebilme derecesine yönelik algılamasıdır (Spreitzer, 1995). İşinde "etkili" olduğunu hissetme, aynı zamanda, bireyin davranışlarının işinde fark yaratabileceğine ilişkin algısıdır (Ergeneli ve Arı, 2005).

Çalışanların psikolojik güçlendirme algısının örgütlerdeki önemine ilişkin Türk yazınında yapılmış araştırmalar mevcuttur (Ergeneli vd., 2007; Tolay vd., 2012; Yürür ve Demir, 2011). Bu çalışmanın katkısı ise, çalışanların psikolojik olarak güçlendirildiğine dair olan algılarının, kişilikleri ve iş tatmini ilişkisi üzerinde aracılık rolünün analiz edilmesidir. Güçlendirme algısı boyutlarının hiçbiri tek başına psikolojik güçlendirmeyi oluşturmamaktadır. Psikolojik güçlendirmenin olabilmesi için, bu boyutların her birinin ayrı ayrı gerçekleşmesi ve güçlendirmenin bütünsel olarak ele alınması gerekmektedir (Spreitzer, 2007). Dolayısıyla, çalışmada çalışanların psikolojik güçlendirmeleri tek bir değişken olarak ele alınacaktır.

Çalışanın psikolojik olarak güçlendirildiğine dair algısı iş tatminini pozitif yönde etkilemektedir (Aryee ve Chen, 2006; Spreitzer vd., 1997). İş tatmini ile ilgili yapılan çalışmalar incelendiğinde iş tatmini ile güçlendirme olgusunun arasında ilişki olduğu görülmektedir. Yöneticilerin, çalışanların güçlendirilmesine yönelik destekleyici davranışları, çalışanların iş tatminlerini de olumlu yönde etkilemektedir (Podsakoff vd., 2000). İş tatmini özellikle psikolojik güçlendirme ile yüksek derecede ilişkilidir (Liden vd., 2000). Psikolojik güçlendirmenin dört boyutu, kişinin işi ile olan ilişkisini şekillendiren psikolojik durumlar olarak tanımlanmaktadır. İşin anlamlılı̆̆ı, psikolojik güçlendirmede anlam boyutunun tecrübe edilmesi ile, iş özerkliliği, özerklik boyutunun tecrübe edilmesi ile, geribildirim ise daha fazla oranda etkinin tecrübe edilmesi ile ilişkili olmaktadır (Kraimer vd., 1999). Psikolojik olarak güçlendirilmiş çalışanlar kendilerini daha kabiliyetli 
görmekte, içinde çalıştıkları örgütü ve işlerini anlamlı bir şekilde etkileyeceklerine inanmaktadırlar. Bu nedenle çalışanlar ekstra performans gösterirler, örgütlerine yüksek derecede bağlılık duyarlar ve iş tatminleri yükselir (Chen vd., 2007; Spreitzer vd., 1997).

Dışa dönüklük ve sorumluluk ile iş tatmini arasındaki pozitif yöndeki ilişki literatürde kanıtlanmış durumdadır (Brief , 1998; Connolly and Viswesvaran, 2000; DeNeve ve Cooper, 1998; Judge vd., 2002; Templer, 2012; Winkelman ve Winkelman, 2008). Bununla birlikte, sorumluluk ile psikolojik güçlendirmenin özellikle yetkinlik ve etki boyutlarının da pozitif ilişkide olduğu belirtilmiştir (Wat ve Shaffer, 2005). Spreitzer (2007), sorumluluk özelliği yüksek olan kişilerin, düzenli ve itinalı olduklarını ve amaçlarına ulaşabilmek için çok çalıştıklarını belirterek, bu tarz kişilerin psikolojik güçlendirmenin yetkinlik boyutunu daha fazla hissedebileceğini belirtmiştir. Öte yandan belirtildiği gibi, güçlendirmenin her boyutu farklı birtakım çıktılara neden olabilmekle birlikte, tek bir boyutun güçlendirmeyi tümden etkilemesi gibi bir durum mümkün olmamaktadır. Yüksek öz saygıya sahip çalışanların psikolojik güçlendirmeyi daha fazla hissettikleri (Spreitzer, 1995) ve öz saygı- Beş Faktör Modeli özellikleri ilişkisinin pek çok araştırmada doğrulandığı görülmektedir (Robins vd., 2001; Pullman ve Allik, 2000). Özellikle dışa dönüklük ve sorumluluk ile öz-saygı arasında güçlü bir ilişki olduğu tespit edilmiştir (Block ve Robins, 1993). Kendine öz saygısı yüksek olan bireyler aynı zamanda işlerine karşı daha fazla yetkinlik hissi taşımaktadırlar. Bu tarz çalışanlar kendilerine daha fazla değer vermekte, örgütlerinde etkilerini daha fazla hissetmekte (Zimmerman, 1990) ve çalıştıkları işe karşı olumlu bir bakış açısı içinde bulunmaktadırlar (Gist ve Mitchell, 1992). Yaptıkları işlerde özenli ve dikkat olup, sorumluluk anlayışları da yüksektir (Gist, 1987). Bunların yanı sıra, ön etkin kişiliğe sahip olan bireylerin belirli durumlarda güçlendirmeyi daha çok hissettikleri belirtilmiştir (Spreitzer, 2007). Hareketli, herhangi bir durumda problem çıkmadan önlemini alan, olaylarda etkin davranan bireyler ön etkin kişilik sahibidir. Bu tarz kişiler, fırsatları kollar, öne atılır, eylemde bulunur ve anlamlı bir fırsat ele geçirene kadar azim gösterirler. Ön etkin kişilik sorumluluk ve dışa dönüklük özelliği ile yakından ilişkili bulunmaktadır (Crant ve Bateman, 2000). Kişilerin olaylara karşı proaktif davranmaları, kişisel girişimlerinin oluşmasına da neden olmaktadır (Frese ve Fay, 2001). Psikolojik güçlendirmenin, ön etkin bir kişiliğin, kişisel girişimi ve daha çok proaktif eğilimlerin ortaya çıkmasına imkan vermesi açısından değerlendirildiğinde, aracı olarak da kullanılabileceği belirtilmiştir (Spreitzer, 2007). Dolayısıyla;

H1: Psikolojik güçlendirme, dışa dönüklük ve iş tatmini arasında aracı bir etkiye sahiptir.

H2: Psikolojik güçlendirme, sorumluluk ve iş tatmini arasında aracı bir etkiye sahiptir.

Belirtildiği gibi, uyumluluk ile iş tatmini arasındaki ilişki ile ilgili olarak literatürde birbirinden farklı görüşler mevcuttur. Uyumluluğun yüksek iş tatminine neden olacağını belirten araştırmalar (McCrae ve Costa, 1991) olduğu gibi, iş tatminini belirlemede etkisiz olduğunu tespit eden araştırmalar (Judge vd., 2002) da bulunmaktadır. Öte yandan, uyumluluk kollektivizm ile olumlu ilişkidedir ve kollektivist bir toplumda bulunan çalışanların, birbirlerine karşı daha duyarlı olacağı ve neticede bireyci toplumlarda çalışanlara kıyasla işlerinden daha fazla tatmin olabilecekleri de belirtilmektedir (Taras vd., 2010). Türk toplumunun kollektivist yapısından dolayı (Hofstede, 1984) ve psikolojik 
güçlendirme ile iş tatmini arasındaki olumlu ilişki (Hechanova vd., 2006; Liden vd., 2000) sebebiyle;

H3: Psikolojik güçlendirme, uyumluluk özelliği ve iş tatmini arasında aracı bir etkiye sahiptir.

Deneyimlere açıklık belirtildiği gibi yaratıcılık, farklı düşünce tarzı, özgün olmak, bağımsız fikirlilik, merak ve sanata duyarlılık ile ilişkili olup (Barrick ve Mount, 1991), Beş Faktör Modeli içerisinde tanımlanması en güç özelliktir (Digman, 1990). Bu özelliğin Zeka (John, 1989) ya da Kültür (Hakel, 1974) olarak tanımlandığı çalışmalar bulunmakla birlikte, içeriğinde çok daha derin bir anlam olduğu ifade edilmektedir (Digman, 1990). Çalışanların deneyimlere açıklığı ile iş tatmin seviyeleri arasındaki ilişki ile ilgili olarak da birbirinden tutarsız sonuçlar elde edildiği de görülmektedir. Bu özelliğin iş tatmine olan etkisinin olmadığını gösteren araştımalar (DeNeve ve Cooper, 1998; Judge vd. 2002) olmasına rağmen olumlu etkisini belirleyen çalışmalar da bulunmaktadır (Ng vd., 2005). Öte yandan, deneyimlere açıklığı yüksek olan çalışanların yeni deneyimlerden sürekli öğrenmeleri sebebiyle, psikolojik güçlendirmenin etki boyutunu daha fazla hissedebilecekleri (Spreitzer, 2007) ve sonuçta işlerinden tatmin olacakları varsayımından hareketle;

H4: Psikolojik güçlendirme, deneyimlere açıklık özelliği ve iş tatmini arasında aracı bir etkiye sahiptir.

Duygusal dengesizlik diğer bir deyişle nevrotizm ise karamsarlık, kaygı, huzursuzluk, endişe ve güvensizlik hissi ile ilişkili olup, iş tatminini en önemli göstergelerinden biridir (Judge vd., 2002). Nevrotik çalışanlar dünyayı negatif bir bakış açısı ile değerlendirdikleri için, duygusal dengesizlikleri mevcut iş koşullarını olumsuz algılamalarına sebep olmaktadır (Connolly ve Viswesvaran, 2000). Nevrotizm aynı zamanda olumsuz duygulanım ile ilişkili olup, bu özellik çalışanların kendilerine verilen görevleri ve yaptıkları işi olumsuz algılama eğiliminde olmalarına neden olmaktadır (Necowitz ve Roznowski, 1994). Bu tarz bireyler, işlerindeki gerçek anlamı görememekte ve kendilerini yetkin olarak değerlendirmemektedir. Duygusal dengesizliği yüksek olan çalışanlar, sıradan olayları bile birer tehdit olarak değerlendirmekte ve tüm bunların neticesinde psikolojik güçlendirmeyi daha az hissederek iş tatmin seviyeleri düşebilmektedir (Spreitzer, 2007). Dolayısıyla;

H5: Psikolojik güçlendirme, duygusal dengesizlik ve iş tatmini arasında aracı bir etkiye sahiptir.

\section{ARAŞTIRMANIN METODOLOJISi}

Araştırmanın amacı çalışanların kişilik özellikleri ile iş tatminleri arasındaki ilişki üzerinde psikolojik güçlendirmenin rolünü incelemektir. Bu amaçla araştırmada veri toplama yöntemi olarak anket kullanmıştır.

\section{1. Örneklem}

Araştırmanın amacına hizmet edebilmek amacıyla eğitim ve bilişim sektörleri seçilmiştir. Özellikle eğitim ve bilişim sektörlerinin seçilmesinin sebebi her iki sektörde de çalışanların eğitim düzeyinin yüksek olmasıdır. Yüksek eğitim düzeyine sahip kişilerin, araştırmada ölçülmesi amaçlanan değişkenlere ilişkin sorulara daha sağlıklı cevap verecekleri 
düşünülmüştür. Eğitim düzeyi aynı zamanda iş tatmini ile ilişkili olan bir unsurdur. Araştırmalar, eğitim düzeyi yüksek olan kişilerin iş tatmin düzeylerinin, daha az eğitim görmüş olanlarla karşılaştırıldığında daha iyi olduğunu göstermektedir (Baysal, 1981). Ayrıca her iki sektör de sürekli ilerleme ve gelişme kaydeden, teknolojinin yakından takip edildiği, belirli standartlara sahip, kişisel gelişim olanakları sunabilen, sürekli bir devinime sahip olan, belirli yeteneklere sahip nitelikli insanları yetiştirme çabası içinde bulunan sektörlerdir. Dolayısıyla hem eğitim, hem de bilişim sektörü bu çalışmada ölçmeye çalışılan psikolojik güçlendirme algısı ve çalışanların iş tatmininin oluşabilmesi için elverişli ortam sunan sektörler olarak değerlendirilmişlerdir. Çalışmada evren seçimi olarak eğitim sektörünü temsil etmek amacıyla Hacettepe ve Bilkent Üniversitesi, bilişim sektörü için ise Ankara'daki iki üniversitenin (Bilkent ve ODTU) teknoparklarında faaliyet gösteren enformasyon ve iletişim teknolojileri ile elektronik gibi alanlarda ARGE faaliyetlerinde bulunan teknoloji şirketleri seçilmiştir.

Toplam 221 kişiden oluşan örneklemin \%54,8'ini erkek, \%45,2'sini kadın çalışanlar oluşturmaktadır. Katılımcıların \%55'i üniversitelerde bulunan öğretim üyelerinden, \%44'ü ise teknoloji şirketlerinde görevli bilgi çalışanlarından oluşmaktadır. Katılımcıların yaş ortalaması $32^{\prime}$ dir $(S=1.05)$. Bulundukları iş yerinde çalıştıkları zaman ortalaması 2.31 senedir $(S=1.44)$. Aynı yönetici ile çalışma süresi ortalama 1.83 senedir $(S=1.44)$.

\subsection{Veri Toplama Araçları}

Demografik Değişkenler. Anketin ilk bölümü demografik değişkenler ile ilgili soruları kapsamaktadır. Çalışanlara, cinsiyet, yaş, aynı iş yerinde ve yönetici ile çalışma süreleri sorulmuştur

Büyük Beşli Kişilik Envanteri. Bu çalışmada çalışanların kişilik özelliklerini ölçmek için John, Donahue ve Kentle (1991) tarafından geliştirilmiş ve Sümer ve diğerleri (2005) tarafından Türkçe'ye çevrilen Büyük Beşli Kişilik Envanteri (Big Five Inventory- BFI) kullanılmıştır. Ölçek 8 maddeden oluşan dışa dönüklük (extraversion), 9 maddelik sorumluluk (conscientiousness), 9 maddelik uyumluluk (agreeableness), 8 maddelik nevrotizm (neuroticism) ve 10 maddelik deneyimlere açıklık (openness to experience) olarak kavramsallaşan 5 alt faktörden oluşmaktadır. Büyük Beşli Kişilik Envanteri, 5'li Likert ölçeğine göre düzenlenmiştir. Örnek ifadeler dışa dönüklük boyutu için "Heyecan ve coşku yaratabilen", sorumluluk için "Planlar yapan ve bunları takip eden", uyumluluk için "Bağışlayıcı bir yapıya sahip", nevrotizm için "Depresif ve hüzünlü ", deneyimlere açıklık boyutu için ise "Hayal gücü yüksek" şeklindedir. Çalışmada kullanılan Büyük Beşli Kişilik Envanteri, Sümer tarafından Türkçe'ye çevrilmiştir. Türkçe'ye uyarlanmış olan kişilik envanterinin alt ölçeklerine ilişkin güvenilirlik katsayılarının 0.64 ile 0.89 arasında olduğu tespit edilmiştir (Sümer vd., 2005; Ulu, 2007). Bu çalışmadaki geçerliğe ilişkin bilgiler bulgular bölümünde verilmektedir.

Minnesota iş Tatmin Anketi. Çalışmada iş tatminini ölçmek için Weiss, Dawis, England ve Lofquist tarafından 1967 yılında geliştirilen Minnesota İş Tatmin Anketi'nin (Minnesota Satisfaction Questionnaire- MSQ) 20 maddeden oluşan kısa formu kullanılmıştır. Ölçek, iş tatmini ile ilgili olarak örgütteki mevcut şartların, çalışanın kendisini ne kadar tatmin edip etmediğine yönelik 5'li Likert ölçeği doğrultusunda oluşturulmuştur. Örnek ifadeler 
"Işimden edindiğim başarı duygusu" ve "Çalışma koşulları" şeklindedir. Minnesota İş Tatmin Ölçeği; "İ̧̧ tatmini, bireyin ihtiyaçlarıyla, bu ihtiyaçları karşılamayı beklediği iş sistemleri arasındaki uyumdan doğar" hipotezine dayanmaktadır. Ölçek, belirtilen 20 iş tatmin boyutu sonucuna göre genel iş tatmini durumunu ortaya koymaktadır ki bu sonuç, ölçeğin 21. boyutu olarak ele alınmaktadır. Ölçekte yer alan ifadeler, iş tatminine yol açan içsel, dışsal ve genel faktörler boyutlarında gruplandırılmaktadır (Weiss vd., 1967). Ölçekte içsel iş tatmini; başarı, tanınma ya da takdir edilme, işin kendisi, yükselme, işin sorumluluğu ve terfi ile bağlantılı görev değişiklikleri gibi işin içsel niteliğine ilişkin tatminkarlıkla alakalı öğelerden oluşmaktadır. Dışsal iş tatmini ise, işletme politika ve uygulamaları, işletmenin denetim şekli, yönetici, astlarla olan ilişkiler, çalışma koşulları ve ücret gibi işin çevresine ait öğelerden meydana gelmektedir. Tüm sorulara verilen cevaplar ise genel iş tatminini ölçmek için kullanılmaktadır. Baycan tarafından (1985) Türkçe'ye çevrilmiş olan ölçeğin Cronbach Alpha iç tutarlılık katsayısı bu çalışmada .88 olarak bulunmuştur.

Psikolojik Güçlendirme Algısı Anketi. Bu çalışmada çalışanların psikolojik olarak güçlendirildiklerine ilişkin algılarını ölçmek için Spreitzer'in (1995) geliştirmiş olduğu "Psikolojik Güçlendirme Algısı Anketi" kullanılmıştır. Ölçek, psikolojik güçlendirmenin anlam, yetkinlik, özerklik ve etki boyutları ile ilgili soruları içeren bir ölçektir. Ölçekte her boyut başına üç sorunun kullanıldığı toplam 12 değerlendirme sorusundan oluşan tek bir ölçüm birimi kullanılmıştır. Ankette yer alan değerlendirmelerin toplanması ile her bir katılımcıya ait psikolojik güçlendirme puanı elde edilmiştir. Psikolojik Güçlendirme Algısı Anketi'nin orijinalinde her bir soru için 7'li Likert kullanılmıştır. Ancak bu çalışmada, 7'li Likert ölçeğinin Türkiye'de kullanımında yaşanan güçlükler ve uyumun sağlanması nedeni ile $5^{\prime}$ li Likert ölçeği uygulanmıştır. Örnek ifadeler anlam boyutu için "Yaptığım iş benim için çok önemlidir", yetkinlik için "Iş̧imi başarmak için gerekli yeteneklere sahip olduğumdan eminim", özerklik için "Iş̧imi nasıl yürüteceğime kendim karar veririm”, etki boyutu için ise "Çalıştığım departmanda olup bitenler konusunda etkim çoktur" şeklindedir. Ölçeğin Türkçe çevirisi Ergeneli ve diğerleri tarafından (2007) yapılmış, bu çalışmada Cronbach Alpha iç tutarlılık katsayısı .83 olarak bulunmuştur.

\section{3. İşlem}

Ömeklemin tespiti için öncelikle Hacettepe Üniversitesi ve Bilkent Üniversitesi'ne gidilerek cevap oranının yüksek olması amacıyla, hazırlanan anket formları, doğrudan öğretim üyelerinin çalıştıkları bölümlere bırakılmıştır. Ayrıca, ODTÜ ve Bilkent Üniversitelerindeki teknoparkların yöneticileri ile görüşülmüş ve teknoparklarda faaliyet gösteren şirketlerin bilgileri alınmıştır. Daha sonra şirketlerin ARGE müdürleri ile telefon görüşmeleri yapılarak çalışma için izin istenmiş ve ARGE çalışanları tespit edilmiştir. Söz konusu ARGE çalışanları ofislerinde ziyaret edilerek anket uygulaması yapılmıştır. Tüm katılımcılara formlara isimlerini yazmamaları ve araştırmanın gizlilik ilkelerine uyacağı iletilmiştir.

Araştırmanın amacına uygun olarak hangi istatistiki tekniklerin kullanılacağını belirlemek için ilk olarak araştırmanın temel değişkenlerinin normal dağılım gösterip göstermediklerini anlayabilmek için ortalama, medyan, standart sapma, basıklık (kurtotis) ve çarpıklık (skewness) değerlerinin yer aldığı tanımlayıcı istatistikler uygulanmıştır. Değişkenlerin normal dağılımı hakkında en çok bilgi sağlayan çarpıklık ve basıklık değerleri 
-1 ile +1 arasında olduğundan dağılımın normalliğinin sağlandığı görülmüştür. Regresyon analizinin yapılabilmesi için örneklem sayısının yeterliği de sağlanmış olmalıdır. Örneklem büyüklüğünü tespit ederken regresyon yöntemi için geçerli olan Tabachnick ve Fidell'in (2001) formülü kullanılarak belirlenen alt sınır (114 katılımcı) bu araştırmada karşılanmış bulunmaktadır. Verilerin analizinde korelasyon analizi, faktör analizi ve hiyerarşik regresyon analizi teknikleri kullanılmıştır.

\section{BULGULAR}

\subsection{Büyük Beşli Kişilik Envanteri'nin (BFI) Faktör Yapısı}

Çalışmada, kişilik özelliği değişkenlerinin orijinal entanter olan Büyük Beşli Kişilik Envanteri'ndeki gibi sınıflanıp sınıflanmadığını görebilmek için faktör analizi yapılmıştır. Yapılan ilk faktör analizi sonucunda 11 faktör elde edilmiştir. Ancak, scree plot grafiği incelendiğinde kırılmanın 5 faktörde gerçekleştiği görülerek, faktör analizi faktör sayısı 5 ile sınırlandırılarak gerçekleştirilmiştir. Ölçeğin faktör analizi yapmaya uygun olup olmadığını belirlemek için Kaiser-Meyer Olkin (KMO) (1970) ve Bartlett (1950) testi değerlerine bakılmıştır. KMO; 0 ile 1 arasında değerler almakta, .50'nin altında olduğunda ise veri kümesi faktörlenememektedir (Field, 2000). Araştırmada kullanılan ölçek için KMO değeri .79 olarak bulunmuştur. Araştırma verilerinden anlamlı faktörler veya değişkenler çıkarılabileceğini gösteren Barlett's Test of Sphericity değeri değerinin istatistiksel olarak anlamlı olduğu tespit edilmiştir. Elde edilen bu bulgular, toplanan bilgilerin faktör analizi yapmak için uygun olduğunu göstermektedir. Yapılan faktör analizinde faktör yükleri .30'un altında çıkan sorular analizlere dahil edilmemiştir. Faktör analizi neticesinde beş kişilik boyutun toplam varyansı açıklama oranı \% 56.94 düzeyinde hesaplanmıştır. Deneyimlere açıklık kişilik özelliğinin sorularını içeren birinci boyut, varyansın \%29.11'ini, sorumluluğun sorularını içeren ikinci boyut, varyansın \%9.47'sini, dışa dönüklük özelliğinin sorularını içeren üçüncü boyut varyansın \%7.62'sini, nevrotizmin sorularını içeren dördüncü boyut varyansın \%6.57'sini, son olarak uyumluluğun sorularını içeren beşinci boyut da varyansın \%4.18'ini açıklamaktadır. Faktör analizi sonucunda faktör yükleri .30 'dan küçük çıkan sorumluluk ile ilgili 13 ve 38 no'lu, nevrotizm ile ilgili 29 no'lu ve uyumluluk ile ilgili 27 no'lu sorular değerlendirmeye alınmamıştır. Büyük Beşli Kişilik Envanteri (BFI) ölçeğine uygulanan faktör analizi neticesinde ortaya çıkan alt boyutlar için hesaplanan Cronbach Alfa iç tutarlılık katsayıları Tablo 1'de gösterilmektedir.

\subsection{Korelasyon Analizi}

Bu çalışmada analizlerden önce tüm araştırma değişkenleri arasındaki korelasyonlar incelenmiştir. Korelasyon analizi sonuçları Tablo 1'de gösterilmektedir. Çalışmanın modelindeki bağımlı değişken olan iş tatmini ile hiçbir demografik değişken arasında bir ilişki bulunmaması sebebi ile, demografik değişkenler (katılımcıların yaşı, cinsiyet, katılımcıların bulundukları iş yerlerinde çalışma süreleri, katılımcıların aynı yönetici ile çalışma süreleri) çalışmada uygulanan analizlere dahil edilmemiştir.

Tablo 1'de görüldüğü gibi çalışanların iş tatminleri ile psikolojik güçlendirme algıları $(r=.46$, $p<.05)$ ve sorumluluk özellikleri $(r=.21, p<.01)$ arasında pozitif yönde anlamlı bir ilişki bulunurken, iş tatmini ve nevrotizm $(r=-.14, p<.05)$ arasında negatif yönde anlamlı bir ilişki 
tespit edilmiştir. Ayrıca psikolojik güçlendirme ile dışa dönüklük $(r=.16, p<.05)$ ve sorumluluk $(r=.14, p<.05)$ arasında pozitif yönde anlamlı bir ilişki belirlenmiş, psikolojik güçlendirme ile nevrotizm $(r=-.17, p<.05)$ arasında ise negatif yönde anlamlı bir ilişki bulunmuştur. 
Tablo 1. Değişkenlere Ait Ortalama, Standart Sapma, Korelasyon ve Güvenirlik Katsayıları

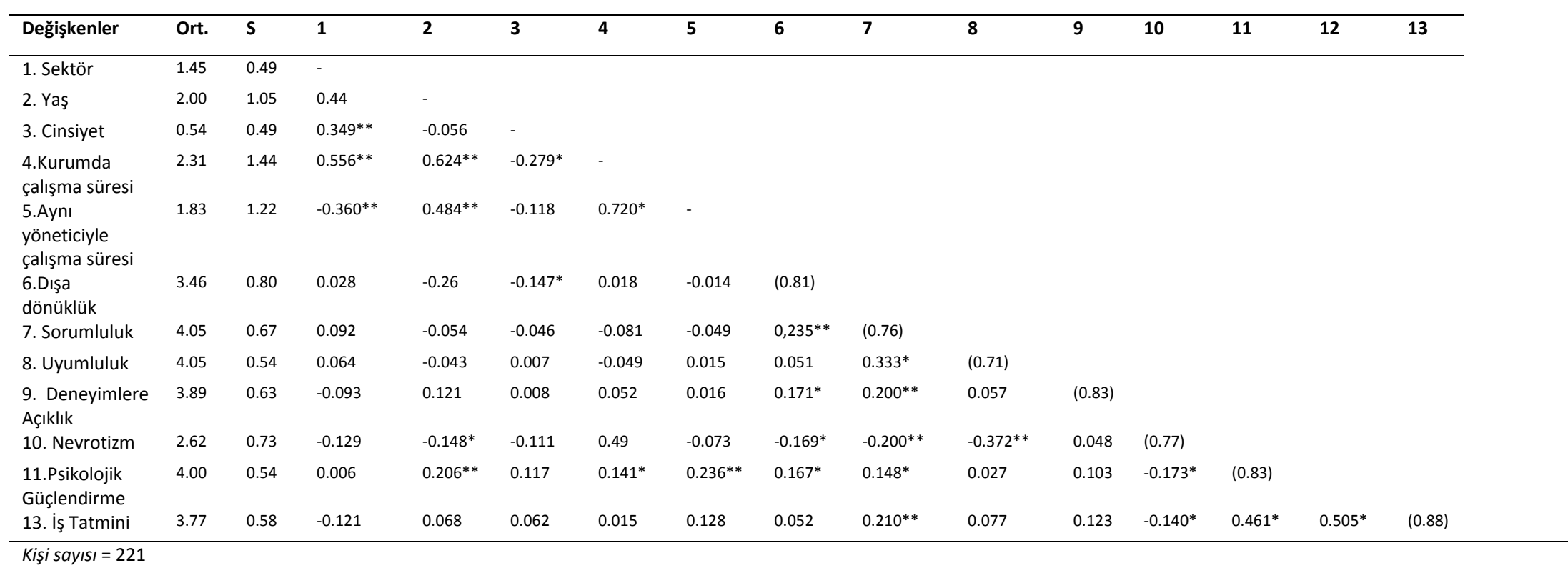

Not: Güvenirlik katsayıları parantezde verilmiştir.

* $p<.05$

$* * p<.01$ 


\subsection{Hipotez Testleri}

Çalışanların psikolojik güçlendirme algılarının, kişilik özellikleri ve iş tatminleri ilişkisi üzerindeki aracılık rolünü belirlemek için Baron ve Kenny (1986) tarafından önerilen regresyon analizi yapılmıştır. Aracılık etkisinin ölçülmesinde dört ayrı regresyon denkleminin kurulması gerekmektedir. Öncelikle, bağımsız değişkenlerin (dışa dönüklük, sorumluluk, uyumluluk, deneyimlere açıklık, nevrotizm) aracı değişkeni (psikolojik güçlendirme) anlamlı bir şekilde yordaması beklenir. İkincil olarak, aracı değişken (psikolojik güçlendirme) ve bağımlı değişken (iş tatmini) arasında anlamlı bir ilişkisinin var olması gerekmektedir. Daha sonra, bağımsız değişkenlerin (dışa dönüklük, sorumluluk, uyumluluk, deneyimlere açıklık, nevrotizm), bağımlı değişken (iş tatmini) üzerinde anlamlı etkisi olması gerekir. Bu analizler sonucunda bir aracılık etkisinden bahsedebilmek için dördüncü regresyon denklemine aracı değişken dahil edildiğinde, bağımsız değişkenin, bağımlı değişken üzerindeki etkisine bakılmaktadır. Bu etkinin azalması durumunda "kısmi aracılık", etkinin tamamen ortadan kalkması durumunda "tam aracılık" etkisinden söz edilebilir. Ancak, aracı değişkenin, bu arada, bağımlı değişken ile arasındaki ilişkinin anlamlılık düzeyini koruması da gerekmektedir (Baron ve Kenny, 1986). Bu doğrultuda psikolojik güçlendirmenin aracılık etkisini belirlemek amacıyla, değişkenler arasındaki ilişkiler hiyerarşik regresyon analizi aracılığıyla incelenmiştir. Elde edilen sonuçlar Tablo 2'de gösterilmektedir. Tablo 2'de çalışanların Beş Faktör Modeli'nde bulunan kişilik özellikleri ile iş tatminleri ilişkisi üzerinde psikolojik güçlendirme algılarının aracılık rolü test edilmiştir. 
Tablo 2: Regresyon Analizi Sonuçları

\begin{tabular}{|c|c|c|c|c|c|c|}
\hline Denklem & Bağımsız Değişken & Bağımlı Değişken & $\mathrm{R}^{2}$ & $\mathrm{~F}$ & $\beta$ & $\mathrm{P}$ \\
\hline $1 a$ & Dışa dönüklük & Psikolojik Güçlendirme & 0.028 & 6.250 & 0.167 & $0.013^{*}$ \\
\hline $1 b$ & Psikolojik Güçlendirme & İş Tatmini & 0.212 & 58.951 & 0.461 & $0.000 * *$ \\
\hline $1 c$ & Dışa dönüklük & Psikolojik Güçlendirme & 0.003 & 0.591 & 0.052 & 0.443 \\
\hline \multirow[t]{2}{*}{$1 d$} & Psikolojik Güçlendirme & & - & - & 0.465 & $0.000 *$ \\
\hline & Dışa dönüklük & İş Tatmini & 0.213 & 29.424 & -0.026 & 0.674 \\
\hline $2 a$ & Sorumluluk & Psikolojik Güçlendirme & 0.022 & 4.852 & 0.148 & $0.029 *$ \\
\hline $2 b$ & Psikolojik Güçlendirme & İş Tatmini & 0.212 & 58.951 & 0.461 & $0.000 * *$ \\
\hline $2 c$ & Sorumluluk & İş Tatmini & 0.044 & 10.095 & 0.210 & $0.002^{*}$ \\
\hline \multirow[t]{2}{*}{$2 d$} & Psikolojik Güçlendirme & & - & - & 0.440 & $0.000 * *$ \\
\hline & Sorumluluk & İş Tatmini & 0,233 & 33,034 & 0,145 & $0,016^{*}$ \\
\hline $3 a$ & Uyumluluk & Psikolojik Güçlendirme & 0.001 & 0.162 & 0.027 & 0.688 \\
\hline $3 b$ & Psikolojik Güçlendirme & İş Tatmini & 0.212 & 58.951 & 0.461 & $0.000 * *$ \\
\hline $3 c$ & Uyumluluk & İş Tatmini & 0.077 & 1.303 & 0.077 & 0.255 \\
\hline \multirow[t]{2}{*}{$3 d$} & Psikolojik Güçlendirme & & - & - & 0.459 & $0.000 * *$ \\
\hline & Uyumluluk & İş Tatmini & 0.217 & 30.044 & 0.065 & 0.284 \\
\hline $4 a$ & Deneyimlere Açıklık & Psikolojik Güçlendirme & 0.011 & 2.353 & 0.103 & 0.126 \\
\hline $4 b$ & Psikolojik Güçlendirme & İş Tatmini & 0.212 & 58.951 & 0.461 & $0.000 * *$ \\
\hline $4 c$ & Deneyimlere Açıklık & İş Tatmini & 0.015 & 3.366 & 0.123 & 0.068 \\
\hline \multirow[t]{2}{*}{$4 d$} & Psikolojik Güçlendirme & & - & - & 0.453 & $0.000 * *$ \\
\hline & Deneyimlere Açıklık & İş Tatmini & 0.218 & 30.331 & 0.076 & 0.206 \\
\hline $5 a$ & Nevrotizm & Psikolojik Güçlendirme & 0.030 & 6.745 & -0.173 & $0.010^{*}$ \\
\hline $5 b$ & Psikolojik Güçlendirme & İş Tatmini & 0.212 & 58.951 & 0.461 & $0.000 * *$ \\
\hline $5 c$ & Nevrotizm & İş Tatmini & 0.020 & 4.344 & -0.140 & $0.038^{*}$ \\
\hline \multirow[t]{2}{*}{$5 d$} & Psikolojik Güçlendirme & & - & - & 0.450 & $0.000 * *$ \\
\hline & Nevrotizm & İş Tatmini & 0.216 & 29.961 & -0.062 & 0.313 \\
\hline
\end{tabular}

H1 Hipotezi'nde psikolojik güçlendirme algısının, dışa dönüklük özelliği ve iş tatmini arasında aracı bir etkiye sahip olduğu öngörülmüştür. 1a no'lu denklemde görüldüğü gibi çalışanların dışa dönüklüğü psikolojik güçlendirme algılarını anlamlı ve pozitif yönde ( $\beta=$ $.167 ; p<.05)$ etkilemektedir. $1 \mathrm{~b}$ no'lu denklemde ise psikolojik güçlendirmenin iş tatminini anlamlı ve pozitif bir şekilde $(\beta=.461 ; p<.01)$ etkilediği görülmektedir. Ancak, $1 c^{\prime}$ de dışa dönüklük kişilik özelliği ile iş tatmini arasında istatistiksel olarak bir ilişki saptanmamış $(\beta=$ .052; $p$ > .05) olması psikolojik güçlendirmenin, dışa dönüklük ve iş tatmini ilişkisi üzerinde anlamlı bir aracı etkisi olmadığını göstermektedir. Dolayısıyla, H1 hipotezi reddedilmiştir.

H2 Hipotezi'nde psikolojik güçlendirme algısının, sorumluluk özelliği ve iş tatmini arasında aracı bir etkiye sahip olduğu öngörülmüştür. $2 a^{\prime}$ da çalışanların sorumluluğunun psikolojik güçlendirme algılarını anlamlı ve pozitif yönde etkilediği $(\beta=0.148 ; p<.05)$ görülmektedir. $2 b^{\prime}$ de psikolojik güçlendirme ve iş tatmini arasındaki anlamlı ilişki $(\beta=.461$; $p<.01$ ) saptanmıştır. $2 c^{\prime}$ de çalışanın sorumluluğunun, iş tatminini olumlu ve anlamlı ( $B=$ $.210 ; p<.01)$ etkilediği tespit edilmiş, sorumluluk ile iş tatmini arasındaki ilişki ise modele psikolojik güçlendirme dahil edildiğinde azalmıştır; 2d'deki beta katsayısının (.145), 2c'de bulunan beta katsayısından (.210) daha küçük olduğu görülmektedir. Elde edilen bu sonuçların ardından aracılık etkisini teyit etmek amacıyla Sobel testi yapılmıştır. Psikolojik 
güçlendirme, sorumluluk ve iş tatmini arasında, Sobel Testi'nin sonuçlarına göre anlamlı olup ( $z=.027 ; p<.05)$ kısmi aracılık özelliği (partial mediation) taşımaktadır. Tüm bu bilgilerden hareketle $\mathrm{H} 2$ hipotezi doğrulanmıştır.

H3 Hipotezi'nde ise psikolojik güçlendirme algısının, uyumluluk özelliği ve iş tatmini arasında aracı bir etkiye sahip olduğu öngörülmüştür. 3a'da görüldüğü gibi uyumluluk ile gerek psikolojik güçlendirme $(\beta=.027 ; p>.05)$, gerekse de iş tatmini $(\beta=.077 ; p>.05)$ arasında istatistiksel olarak anlamlı bir ilişki tespit edilmediğinden ötürü H3 hipotezi reddedilmiştir.

H4 Hipotezi'nde psikolojik güçlendirme algısının, deneyimlere açık olma özelliği ve iş tatmini arasında aracı bir etkiye sahip olduğu öngörülmüştür. 4a'da deneyimlere açıklık ile psikolojik güçlendirme $(\beta=.103 ; p>.05)$ arasında anlamlı bir ilişki bulunmamıştır. $4 c^{\prime}$ de ise deneyimlere açık olma ile iş tatmini arasında zayıf yönde anlamlı bir ilişki $(\beta=.123 ; p<.10)$ tespit edilmiştir. Bu verilerden hareketle, $\mathrm{H} 4$ hipotezi reddedilmiştir.

Son olarak, H5 Hipotezi'nde psikolojik güçlendirme algısının, nevrotizm ve iş tatmini arasında aracı bir etkiye sahip olduğu öngörülmüştür. 5a no'lu denklem nevrotizmin psikolojik güçlendirmeyi anlamlı ve negatif yönde etkilediğini $(\beta=-.173 ; p<.01), 5 b$ ise psikolojik güçlendirme ile iş tatmini arasındaki anlamlı ve pozitif ilişkiyi $(\beta=.461 ; p<.01)$ göstermektedir. $5 c^{\prime}$ de nevrotizm iş tatminini anlamlı ve negatif olarak etkilemekte $(\beta=-$ $.140 ; p<.05)$ ancak bu etki analize aracı değişken olan psikolojik güçlendirme dahil edildiğinde ortadan kalkmaktadır $(\beta=-.062 ; p>.05)$. Bu durumda, "tam aracılık" (full mediator) etkisi mevcuttur. Dolayısıyla, psikolojik güçlendirme, nevrotizm ile iş tatmini arasında tam aracı etkisine sahiptir ve $\mathrm{H} 5$ hipotezi doğrulanmıştır.

\section{TARTIŞMA ve SONUÇ}

$\mathrm{Bu}$ araştırmada çalışanların kişilik özellikleri, psikolojik güçlendirme algıları ve iş tatmin değişkenlerinin arasındaki ilişki ve etkiler incelenmiştir. Bu amaçla eğitim ve bilişim sektöründe çalışanlardan konu ile ilgili veriler toplanmış ve bu veriler sayesinde araştırmacılar tarafından geliştirilmiş olan model test edilmiştir. Bu model, çalışanların psikolojik güçlendirme algılarının, kişilik özellikleri ve iş tatminleri üzerindeki etkisindeki aracılık rolünü incelemektedir. Örneklemden elde edilen veriler ve model kapsamında yapılan analizler neticesinde, öğretim üyeleri ve bilgi çalışanları açısından, araştırmanın değişkenlerine ilişkin bulgulara ulaşılmıştır.

Araştırma sonuçları incelendiğinde, çalışanın dışa dönüklük özelliğinin, psikolojik olarak güçlendirilmesini olumlu yönde etkilediği sonucu elde edilmiştir. Çalışanların dışa dönük olmaları, olaylara karşı proaktif davranmalarına ve kişisel girişimlerinin de oluşmasına neden olacak (Frese ve Fay, 2001), dolayısıyla bu tarz çalışanlar psikolojik güçlendirmeyi daha fazla hissedebileceklerdir. Literatür incelendiğinde Beş Faktör kişilik özelliklerinin, psikolojik güçlendirmeyi nasıl etkilediğine dair az sayıda araştırma yapıldığı (Crant ve 
Bateman, 2000; Spreitzer, 1995) ve yapılan araştırmaların da kesin tespitler değil varsayımlar şeklinde olduğu görülmektedir. Bu açıdan bakıldığında çalışanın dışa dönüklük özelliğine sahip olmasının, psikolojik olarak güçlendirilmesini olumlu şekilde etkilediği bulgusunun literatüre katkı sağlayacağı düşünülmektedir.

Araştırma sonuçları aynı zamanda psikolojik güçlendirmenin iş tatminini olumlu yönde etkilediğini göstermektedir. Bu sonuç, literatürdeki benzer araştırmalarla da paralellik göstermektedir (Aryee ve Chen, 2006; Chen vd., 2007; Conger ve Kanungo, 1988; Hechanova vd., 2006; Liden vd., 2000; Spreitzer vd., 1997; Thomas ve Velthouse, 1990). Psikolojik olarak güçlendirilme doğrudan çalışanın davranışlarını etkilemektedir. Yöneticilerin, çalışanların güçlendirilmesine yönelik destekleyici davranışları, çalışanların iş tatminlerini olumlu yönde etkiler (Podsakoff vd., 1996). Psikolojik olarak güçlendirilmiş çalışanlar kendilerini daha kabiliyetli görmekte, çalıştıkları örgütü ve işlerini anlamlı bir şekilde etkileyeceklerine inanmaktadırlar. Bu nedenle, çalışanlar ekstra performans göstermekte, örgütlerine yüksek derecede bağlılık duymakta ve neticede iş tatminleri yükselmektedir.

Çalışma sonuçlarına göre, çalışanın dışa dönüklük kişilik özelliği ile iş tatmini arasındaki ilişki bir ilişki saptanmamıştır. Elde edilen bu bulgu literatürden farklılaşmaktadır. Şöyle ki, literatürde bu konu ile ilgili yapılmış olan araştırmalarda çalışanların dışa dönük olmalarının iş tatminlerini olumlu yönde etkilediği tespit edilmiştir (Barrick ve Mount, 1991; Judge vd., 2008; Ng vd., 2005; Tanoff ve Oregon, 1999).

Araştırmada, çalışanın sorumluluk özelliğinin, psikolojik olarak güçlendirilmesini olumlu yönde etkilediği sonucu elde edilmiştir. Literatür incelendiğinde bu konuda literatürde çok az sayıda araştırma yapıldığı görülmektedir. Sorumluluk özelliği yüksek olan kişiler, düzenli, itinalı, planlı, organize, hedef ve görev odaklı olduklarından dolayı psikolojik güçlendirmeyi ve psikolojik güçlendirmenin özellikle yetkinlik boyutunu daha çok hissetmektedirler (Spreitzer, 2007). Sorumluluk özelliği yüksek olan çalışanların aynı zamanda psikolojik güçlendirmenin diğer bir boyutu olan anlam boyutunu da diğer kişilerden daha fazla hissedecekleri düşünülebilir. Çalışanın, yaptığı işin anlamlı olduğuna ilişkin algısı neticede onun işten elde edeceği tatmin düzeyini ve güçlendirme duygusunu etkilemektedir (Spreitzer, 1995). Dolayısıyla, işlerinde ilerlemeye odaklanmış, sorumluluk düzeyi yüksek olan kişiler, psikolojik güçlendirmeden daha çok fayda sağlamaktadır (Spreitzer, 2007).

Yapılan analizler sorumluluğun aynı zamanda iş tatminini de olumlu yönde etkilediği sonucunu ortaya çıkarmıştır. Bu sonuç literatürde yapılmış olan araştırmalarla da paralellik göstermektedir (Barrick ve Mount, 1991; Judge vd., 2002; Ng vd., 2005; Raja ve Johns, 2004; Tanoff ve Oregon 1999; Winkelmann ve Winkelmann, 2008). Sorumlu çalışanlar yaptıkları işe kendilerini verir ve kendilerine verilen görevleri en iyi şekilde yapmaya gayret ederler (Costa ve McCrae, 1995). Sorumluluk özelliği yüksek olan çalışanların işe devamsızlıkları düşük olduğu, buna karşın iş tatminleri yüksek olduğu belirlenmiştir (Furnham vd., 2002). 
$\mathrm{Bu}$ araştırmada çalışanların sorumluluk özellikleri ile iş tatminleri arasında psikolojik güçlendirmenin aracı etkisi olduğu tespit edilmiştir. Yapılan analizler neticesinde, psikolojik güçlendirme, sorumluluk ile iş tatmini ilişkisi üzerinde kısmi aracılık etkisine sahip olarak bulunmuştur.

Öte yandan bu araştırmada psikolojik güçlendirmenin, çalışanların dışa dönüklüğü, uyumluluğu ve deneyimlere açıklığı ile iş tatmini arasında aracı bir etkisi olmadığı tespit edilmiştir. Çalışanın deneyimlere açıklık özelliği ile psikolojik olarak güçlendirilmesi arasında da bir ilişki saptanmamıştır. Öte yandan elde edilen bu sonuç literatürde deneyimlere açıklık özelliği ile psikolojik güçlendirme arasındaki ilişki ile ilgili yapılan varsayımlarla farklılaşmaktadır. Deneyimlere açık olan kişilerin de, psikolojik güçlendirmeyi hissedebilecekleri, bu tahminin nedeninin ise bu tarz kişilerin yaşadıkları tecrübelerden ders almaları ve yeni deneyimler edinmek için değişik yollar aramaları olduğu belirtilmektedir (Spreitzer, 2007). Conger ve Kanungo (1988) psikolojik güçlendirmenin örgütlerde yenilikçi davranışları canlandırarak, çevresel birtakım engellere rağmen, bireylerde mücadele güdüsü yarattığını ifade etmiştir. Girişimci örgütlerde inceleme yapan Kanter (1983), güçlendirme ve yenilikçi davranışların birbiriyle ayrılamaz şekilde ilişkili olduğunu belirtmiştir. Deneyimlere açık kişilerin yeniliğe ve değişime açık olmalarından dolayı bu özelliğin psikolojik güçlendirme ile ilişkili olabileceği düşünülebilir. Ancak literatürde deneyimlere açıklık özelliği ile psikolojik güçlendirme arasındaki ilişkiye yönelik kesin bir tespitle karşılaşılmamıştır.

Araştırmada deneyimlere açıklığın, iş tatminini zayıf da olsa olumlu olarak etkilediği tespit edilmiştir. Deneyimlere açıklık ile iş tatmini ilişkisi ile ilgili literatüre bakıldığında tutarlı sonuçlar elde edilmediği göze çarpmaktadır. Bazı araştırmalar (Barrick ve Mount, 1991; Ng vd., 2005) deneyimlere açıklık ile iş tatmini arasında olumlu ilişki olduğunu tespit etmiş olsa da, bazı araştırmalarda (Tanoff ve Oregon, 1999), deneyimlere açıklık ile iş tatmini arasında ilişki olmadığı sonucu elde edilmiştir.

Araştırmada son olarak çalışanların psikolojik güçlendirme algılarının, nevrotizm özellikleri ile iş tatminleri arasında tam aracılık etkisinde bulunduğu sonucu elde edilmiştir. Duygusal dengesizliğe sahip olan kişiler dünyayı negatif bir bakış açısı ile değerlendirdikleri ve sıradan olaylardan dahi rahatsızlık duydukları için psikolojik olarak güçlendirilmeyi de diğerlerine kıyasla daha az hissedeceklerdir. Bu tarz kişiler, işlerindeki anlamı görebilmek için kendilerine sağlanmış olan olanakları fark edemeyebilirler. Sonuçta kendilerini daha az yetkin olarak değerlendirirler ve psikolojik olarak güçlendirilmeleri diğer insanlara göre çok daha zor olur (Spreitzer, 2007) ve neticede de iş tatminleri düşer. Endişeli, karamsar ve depresif yapıdaki nevrotik bir kişi çalıştığı iş yerinde psikolojik olarak güçlendirilmediğini hissetmesi sebebiyle, iş ortamına ait süreç veya olayları, gerçeği yansıtsın ya da yansıtmasın, olumsuz bir biçimde algılayacak ve iş tatminsizliği yaşayacaktır.

Sonuç olarak, görülmektedir ki sorumlu çalışanların işlerinden tatmin olabilmeleri psikolojik güçlendirmenin kısmi aracılığıyla, nevrotik çalışanların işlerinden tatmin olabilmeleri ise psikolojik güçlendirmenin tam aracılığı ile gerçekleşmektedir. Dışa dönük, 
uyumlu ve deneyimlere açık olan çalışanların işlerinden tatmin olabilmelerinde psikolojik güçlendirmenin aracılık etkisi yoktur. Daha önce gerek Türk yazınında, gerekse de uluslararası yazında bu tarz bir araştırma yapılmamış olması sebebi ile bu sonuçların literatüre önemli katkıda bulunacağı düşünülmektedir.

\section{KISITLAR VE ÖNERILER}

Her çalışmada olduğu gibi, bu çalışmanın da bazı kısıtları bulunmaktadır. Öncelikle, çalışmanın sadece iki sektörde çalışan bireylere uygulanmış olması, bireylerin ortak kültürü paylaşmalarından ötürü, bireysel özellikler bakımından birbirlerine benzemelerine ve benzer düşünceleri paylaşmalarına sebep olabilmektedir. Örneklemin nispeten homojen olmasının çalışmanın genellenebilir olmasını engelleyebileceği düşünülebilir. Çalışmanın diğer bir kısıtı da araştırmada kullanılan ölçeklerin bireysel değerlendirmeye yönelik olmasıdır. Bazı araştırmacılar (Schwarz, 1999) bireysel değerlendirmelerde, kişilerin kendilerini olduklarından daha iyi gösterebileceklerini, sorularda cümle yapısındaki veya kelimelerdeki en küçük değişikliklerin bile sonucu etkileyebileceğini öne sürmektedir. Her ne kadar bireysel değerlendirmeli ölçekler eşleştirmeli veri toplamanın sebep olabileceği karışıklık, güvensizlik ve yanıltıcılıktan kaçınmak için seçilmişse de, bireysel değerlendirmelerin de kendine özgü zayıf yönleri mevcuttur. Örneğin Hofstee (1994), bireysel değerlendirmelerden toplanan verilerin, eşleştirmeli verilere göre güvenilirliğinin daha düşük olduğunu belirtmiştir. Son olarak çalışanların kişilik özellikleri ile iş tatminleri ilişkisi üzerinde psikolojik güçlendirme etkisini belirlemeye yönelik oluşturulan araştırma modelinin literatürde benzerine rastlanmamaktadır. Dolayısıyla, konuyla ilgili yayınların kısıtlı olması, araştırma sonuçlarının bazılarının diğer araştırmalarla karşılaştırılmasına, benzer ya da farklı yönlerin tartışılmasına sınırlama getirmiştir. Öte yandan bu sınırlama, çalışmanın literatüre yaptığı katkı bakımından önemlidir.

Gelecek araştırmalarda, alan araştırmasının çeşitli sektörlerde ve farklı şehirlerde faaliyet gösteren çalışanlar üzerinde uygulanması çalışmanın genellenebilirliğini arttırabilir. Son olarak, bu çalışma sadece çalışan açısından değerlendirilmiştir. İleriki araştırmalarda, kişilik özellikleri ile ilgili soruların yöneticilere de sorulması yoluyla yeni bakış açıları yaratılabilir ve farklı karşılaştırmalar yapılabilir.

Rekabet koşullarının giderek zorlaştığı, dinamik çevrelerdeki değişimlerin gün geçtikçe hızlandığı ve örgütlerin tüm bunlara ayak uydurabilmek ve ayakta kalabilmek için kendilerini sürekli geliştirmeye çalıştığı günümüzde, örgütsel amaçların gerçekleştirilebilmesi hususu yöneticiler için giderek daha fazla önem kazanmaktadır. Örgütsel hedeflere ulaşabilmek için öncelikle çalışanların ve örgütün hedefleri arasında uyum olmalıdır. Çalışanların beklentileri ve örgütün amaçları arasında istenen bağın kurulması örgütün devamlılığı açısından son derece önemlidir. Bu da büyük ölçüde çalışanların kişiliğine bağlıdır. Çalışanların kişilik özelliklerinin, çalıştıkları işleri ve çevrelerini algılamalarında ve değerlendirmelerinde önemli bir etkisi bulunmaktadır. 
Dolayısıyla yöneticilerin, çalışanların kişilik özelliklerini göz önünde bulundurmaları gerekmektedir. Hem yeni iş adayları, hem de mevcut çalışanların kişilik boyutları belirlenerek, onlara karşı nasıl bir davranış ve tutum içinde olunacağı kestirilebilir ve belirli işlere belli kişilik özelliklerine sahip çalışanların yerleştirilmesinde daha fazla fayda sağlanabilir. Ayrıca işe alım sırasında sorumluluğu yüksek olan kişilerin seçilmesi örgütün yararına olacaktır.

Yöneticilerin aynı zamanda çalışanların iş tatminlerinin artmasında etkili olan psikolojik güçlendirmeye önem vermeleri gerekmektedir. Bunların yanı sıra sorumluluk ve duygusal dengesi yüksek seviyede olan çalışanlara daha fazla psikolojik güçlendirme yapılmalıdır ki bu çalışanlardan daha fazla performans sağlanabilsin.

Çalışanların kişilik özellikleri, psikolojik olarak güçlendirilmeleri ve iş tatminleri kavramlarının tümü birbirleriyle ilişkili ve birlikte düşünülmesi gereken unsurlardır. Yöneticilerin etkin bir yönetim sergileyebilmeleri için tüm bu unsurları dikkate almaları ve örgüt içinde gerek davranış kalıpları, gerek hiyerarşik düzenlemeler, gerekse de uygulanan eğitimler açısından ihtiyaç duyulan düzenlemeleri yerine getirmeleri örgütün başarısı ve devamııı̆ı için dikkate alınması gereken olgulardır.

\section{KAYNAKLAR}

Acuna, S. T., Gómez, M. ve Juristo, N. (2009), How do personality, team processes and task characteristics relate to job satisfaction and software quality?, Information and Software Technology, 51, s.627-639.

Aryee, S. ve Chen, Z. X. (2006), Leader-member exchange in a Chinese context: Antecedents, the mediating role of psychological empowerment and outcomes, Journal of Business Research, 59, s.793-801.

Aydogdu, S. ve Asıkgil, B. (2011), An Empirical Study of the Relationship Among Job Satisfaction, Organizational Commitment and Turnover Intention, International Review of Management and Marketing, 1(3), s.43-53.

Aydogmus, C. (2011), Kişilik Özellikleri ile İş Tatmini ïlişkisi Üzerinde Psikolojik Güçlendirme ve Dönüşümcü Liderlik Algısının Etkileri, Doktora Tezi, Hacettepe Üniversitesi Sosyal Bilimler Enstitüsü, Ankara.

Baron, R. M. ve Kenny, D. A. (1986), The moderator-mediator variable distinction in social psychological research: Conceptual, strategic, and statistical considerations, Journal of Personality and Social Psychology, 51, s.11731182.

Barrick, M. R. ve Mount, M. K. (1991), The Big Five personality dimensions and job performance: A meta-analysis, Personnel Psychology, 44, s.1-26.

Barrick, M. R., Mount, M. K. ve Judge, T. A. (2001), Personality and performance at the beginning of the new Millennium: What do we know and where do we go next?, International Journal of Selection and Assessment, 9, s.9-30.

Bartlett, M. S. (1950), Tests of significance in factor analysis, British Journal of Psychology, Statistical Section, 3, s.77-85.

Basım, H. N., Çetin, A. ve Tabak, A. (2009), Beş Faktör Kişilik Özelliklerinin Kişilerarası Çatışma Çözme Yaklaşımlarıyla İlişkisi, Türk Psikoloji Dergisi, 24 (63), s.20-34.

Baycan, A. (1985), An analysis of several aspects of job satisfaction between different occupational groups, Yayınlanmamış Yüksek Lisans Tezi, Boğaziçi Üniversitesi, İstanbul. 
Baysal A. C. (1981), Sosyal ve Örgütsel Psikolojide Tutumlar, İstanbul: Yalçın Ofset Matbaası.

Block J. ve Robins, R. W. (1993), A Longitudinal Study of Consistency and Change in Self-Esteem from Early Adolescence to Early Adulthood, Child Development, 64 (3), s.909-923.

Brief, A.P. (1998), Attitudes in and around organizations, Thousand Oaks, CA: Sage.

Can, H., Aşan, Ö. ve Aydın, E. M. (2006), Örgütsel Davranış, İstanbul: Arıkan Basım Yayım Dağıtım.

Chen, G., Kirkman, B. L., Kanfer, R., Allen, D. ve Rosen, B. (2007), A multilevel study of leadership, empowerment, and performance in teams, Journal of Applied Psychology, 92 (2), s.331-346.

Choi, J. N. (2004), Individual and contextual predictors of creative performance: The mediating role of psychological processes, Creativity Research Journal, 16, s.187-199.

Conger J. A. ve Kanungo, R. N. (1988), The empowerment process: Integrating theory and practise, Academy of Management Review, 13 (3), s.471-482.

Connolly, J. ve Viswesvaran, C. (2000), The role of affectivity in job satisfaction: a meta-analysis, Personality and Individual Differences, 29, s.265-281.

Costa, P. T. ve McCrae, R. R. (1985), The NEO Personality Inventory manual, Odessa, FL: Psychological Assessment Resources.

Costa, P. T. Jr. ve McCrae, R. R. (1992), Revised NEO Personality Inventory (NEO-PI-R) and NEO Five-Factor (NEO$\mathrm{FFI})$ Inventory professional manual, Odessa, FL: Psychological Assessment Resources.

Costa, P. T., McCrae, R. R. ve Dye, D. A. (1991), Facet scales for agreeableness and conscientiousness: A revision of the NEO personality inventory, Personality and Individual Differences, 12, s.887-898.

Crant J. M. ve Bateman T. S. (2000), Charismatic leadership viewed from above: The impact of proactive personality, Journal of Organizational Behavior, 21, s.63-75.

Çalışkan, A. ve Hazır, K. (2012), Psikolojik Güçlendirmenin İş Tatminine Etkisinde Örgütsel Bağlılığın Aracılık Rolü, Cag University Journal of Social Sciences, 9(2), s.48-76.

Çekmecelioğlu, H.G. (2005), Örgüt ikliminin iş tatmini ve işten ayrılma niyeti üzerindeki etkisi: Bir araştırma, İktisadi ve İdari Bilimler Dergisi, 6(2), s.23-39.

DeNeve, K. ve Cooper, H. (1998), The happy personality: A meta-analysis of 137 personality traits and subjective well-being, Psychological Bulletin, 124 (2), s.197-229.

Digman, J. M. (1990), Personality structure: Emergence of the Five Factor Model, Annual Review of Psychology, 41, s.417-440.

Ergeneli, A. (2006), Örgüt ve İnsan, Ankara: Hacettepe Üniversitesi Hastaneleri Basımevi.

Ergeneli, A. ve Arı, G. S. (2005), Krizde işten çıkarmaların banka yöneticileri üzerine etkileri: Örgütsel bağlılık, güven ve güçlendirme algıları, Ankara Üniversitesi Siyasal Bilgiler Fakültesi Dergisi, 60 (1), s.121-148.

Ergeneli, A., Sag, G., Ari, I. ve Metin, S. (2007), Psychological empowerment and its relationship to trust in immediate managers, Journal of Business Research, 60 (1), s.41-56.

Erstad, M. (1997), Empowerment and organizational change, International Journal of Contemporary Hospitality Management, 9 (7), s.325-333.

Field, A. (2000), Discovering Statistics using SPSS for Windows, London -Thousand Oaks- New Delhi: Sage Publications.

Frese, M. ve Fay, D. (2001), Personal initiative: An active performance concept for work in the 21st century, B. M. Staw \& R. I. Sutton (Eds.), Research in Organizational Behavior, 23, s.133-187.

Furnham, A., Tang, T., Lester, D., O'Connor, R. ve Montgomery, R. (2002), Estimates of ten multiple intelligences, European Psychologist, 7, s.245-235.

Gist, M. E. (1987), Self-efficacy: Implications for organizational behavior and human resource management, Academy of Management Review, 12 (3), s.472-485. 
Gist, M. E. ve Mitchell, T. R. (1992), Self-efficacy: A theoretical analysis of its determinants and malleability, Academy of Management Review, 2, s.183-211.

Graziano, W. G. ve Eisenberg, N. (1997), Agreeableness: A dimension of personality. R. Hogan, J. Johnson, \& S. Briggs (Eds.), Handbook of personality psychology, San Diego, CA: Academic Press, s.767-793.

Gürbüz, S. ve Yüksel, M. (2008), Çalışma ortamında duygusal zeka: İş performansı, iş tatmini, örgütsel vatandaşlık davranışı ve bazı demografik özelliklerle ilişkisi, Doğuş Üniversitesi Dergisi, 9 (2), s.174-190.

Hakel, M. D. (1974), Normative personality factors recovered from ratings of personality descriptors: The Beholder's Eye, Personnel Psychology, 27 (3), s.409-421.

Hechanova, M., Alampay, R. ve Franco, E. (2006), Psychological empowerment, job satisfaction, and performance among Filipino service workers, Asian Journal of Social Psychology, 9, s.92-78.

Hofstede, G. (1984), Culture's consequences: International differences in work-related values, Beverly Hills, CA: Sage Publications.

Hofstee, W. K. B. (1994), Who should own the definition of personality?, European Journal of Personality, 8, s.149-162.

Holland, J. L. (1985), Making vocational choices: A theory of vocational personalities and work environments, Odessa, FL: Psychological Assessment Resources.

Honold, L. (1997), A Review of the Literature on Employee Empowerment, Empowerment in Organizations, 5 (4), s.202-212.

John, O. P. (1989), Towards a taxonomy of personality descriptors, D. M. Buss ve N. Cantor (Eds.), Personality psychology: Recent trends and emerging directions, New York: Springer-Verlag, s. 261-271.

John, O. P., Donahue, E. M. ve Kentle, R. L. (1991), The Big Five Inventory--Versions 4a and 54, Berkeley: University of California, Berkeley, Institute of Personality and Social Research.

Judge, T. A. ve Bono, J. E. (2000), Five-factor model of personality and transformational leadership, Journal of Applied Psychology, 85, s. 751-765.

Judge, T. A., Bono, J. E., Locke ve E. A. (2000), Personality and job satisfaction: The mediating role of job characteristics, Journal of Applied Psychology, 85(2), s.237-249.

Judge, T. A., Heller, D. ve Klinger, D. (2008), The Dispositional Sources of Job Satisfaction: A Comparative Test, Applied Psychology: An International Review, 57(3), s.361-372.

Judge, T. A., Heller, D. ve Mount, M.K. (2002), Five-factor model of personality and job satisfaction: A metaanalysis, Journal of Applied Psychology, 87 (3), s. 530-541.

Judge, T. A. ve Larsen, R. J. (2001), Dispositional affect and job satisfaction: A review and theoretical extension, Organizational Behavior and Human Decision Processes, 86, s. 67-98.

Judge, T. A., Parker, S., Colbert, A. E. Heller, D. ve Illies, R. (2001), Job Satisfaction: A Cross-Cultural Review, Handbook of Industrial, Work \& Organizational Psychology, Sage. ND JOB.

Kaiser, H. F. (1970), A second generation little jiffy, Psychometrika, 35, s.401-415.

Kanter, R. M. (1983), The Change Masters, Simon and Schuster, New York.

Karatepe, O. M., Uludağ O., Menevis, İ., Hadzimehmedagic, L. ve Baddar, L. (2006), The effects of selected individual characteristics on frontline employee performance and job satisfaction, Tourism Management, 27 (4), s.547-560.

Kim, T. Y. ve Leung, K. (2007), Forming and reacting to overall fairness: A crosscultural comparison, Organizational Behavior and Human Decision Processes, 104(1), s.83-95.

Kraimer, M. L., Seibert, S. E. ve Liden, R.C. (1999), Psychological empowerment as a multidimensional construct: A test of construct validity, Educational and Psychological Measurement, 59, s.127-142. 
Liden, R. C. ve Arad, S. (1996), A power perspective of empowerment and work groups: Implication for HRM research, G.R. Ferris (Ed.), Research in personnel and HRM, Greenwich, CT: JAI Press, 14, s.205-252.

Liden, R., Wayne, S. ve Sparrowe, R. T. (2000), An Examination of the Mediating Role of Psychological Empowerment on the Relations Between the Job, Interpersonal Relationships and Work Outcomes, Journal of Applied Psychology, 85 (3), s.407-416.

Locke, E. A. (1976), The nature causes and causes of job satisfaction, M.C. Dunnette (Ed.), Handbook of Industrial and Organizational Psychology, Chicago: Rand McNally, s.1279-1349.

Manojlovich, M., Laschinger, S. ve Heather K. (2002), The Relationship of Empowerment and Selected Personality Characteristics to Nursing Job Satisfaction, Journal of Nursing Administration, 32 (11), s.586-595.

McCrae, R. R. ve Costa, P. T. (1989), Rotation to maximize the Construct Validity of Factors in NEO Personality Inventory, Multivariate Behavioral Research, 24 (1), s.107-124.

McCrae, R. R. ve Costa, P. T. (1991), Adding Liebe und Arbeit: The Full Five-Factor Model and Well-Being, Journal of Personality and Social Psychology, 817 (2), s.227-232.

Motowidlo, S. J. (1996), Orientation toward the job and organization. K.R. Murphy (Ed.), Individual differences and behavior in organization, San Francisco, CA: Jossey-Bass, s.175-208.

Moyle, P. (1995), The role of negative affectivity in the stress process: Tests of alternative models. Journal of Organizational Behavior, 16, s.647-668.

Necowitz, L. B. ve Roznowski, M. (1994), Negative Affectivity and Job Satisfaction: Cognitive Processes Underlying the Relationship and Effects on Employee Behaviors, Journal of Vocational Behavior, 45 (3), s.270-294.

$\mathrm{Ng}$, T., Eby, L.T., Sorensen, L.L. ve Feldman, D.C. (2005), Predictors of Objective and Subjective Career Success: A meta-analysis, Personnel Psychology, 58, s.367-408.

Organ, D. W. ve Ryan, K. (1995), A meta-analytic review of attitudinal and dispositional predictors of organizational citizenship behavior, Personnel Psychology, 48, s.755-802.

Özgen, H., Öztürk, A. ve Yalçın, A. (2002), İnsan Kaynakları Yönetimi, Adana: Nobel Yayınevi.

Podsakoff, P. M., MacKenzie, S. B. ve Bommer, W. H. (1996), Transformational leader behaviors and substitutes for leadership as determinants of employee satisfaction, commitment, trust and organizational citizenship behaviors, Journal of Management, 22 (2), s.259-298.

Podsakoff, P. M., MacKenzie, S. B., Paine, J. B. ve Bachrach, D. G. (2000), Organizational citizenship behavior: A critical review of the theoretical and empirical literature and suggestions for future research, Journal of Management, 26, s.513-563.

Pullmann, H. ve Allik, J. (2000), The Rosenberg Self-Esteem Scale: Its dimensionality, stability and personality correlates in Estonian, Personality and Individual Differences, 28, s.701-715.

Raja, U. ve Johns, G. (2004), The impact of personality on psychological contracts, Academy of Management Journal, 47, s.350-367.

Robins, R. W., Tracy, J. L., Trzesniewski, K., Potter, J. ve Gosling, S. D. (2001), Personality Correlates of SelfEsteem, Journal of Research in Personality, 35, s.463-482.

Rusting, C. L. Ve Larsen, R. J. (1997), Extraversion, neuroticism, and susceptibility to positive and negative affect: A test of two theoretical models, Personality and Individual Differences, 22 (5), s.607-612.

Salgado J. F. ve De Fruyt F. (2005), Personality in personnel selection, Evers A, Anderson N, Smit-Voskuijl (Ed.), Handbook of Personnel Selection, Oxford, UK: Blackwell, s.174-198.

Samad, S. (2006), Predicting Turnover Intentions: The Case of Malaysian Government Doctors, The Journal of American Academy of Business, 8 (2), s.113-119.

Schmitt, D. P., Allik, J., McCrae, R. R. ve Benet-Martinez, V. (2007), The geographic distribution of big five personality traits: pattern and profiles of human self-description across 56 nations. Journal of Cross-Cultural Psychology, 38, s.173-212. 
Schoderbek, P. P., Cosier, R. A. ve Aplin, J. C. (1991), Management, Harcourt Brace Jovanovich Publishers, USA. Schwarz, N. (1999), Self-Reports: How the questions shape the answers?, American Psychologist, 54 (2), s.93-105. Somer, O. ve Goldberg, L. R. (1999), The structure of Turkish trait-descriptive adjectives, Journal of Personality and Social Psychology, 76, s.431-450.

Somer, O., Tatar, A. ve Korkmaz, M. (2001), Çok Boyutlu Kişilik Ölçeğinin Geliştirilmesi, Ege Üniversitesi, Araştırma Projesi Raporu.

Spreitzer, G. M. (1995), Psyhological Empowerment In The Workplace: Dimensions, Measurement, and Validation, Academy of Managemet Journal, 38 (5), s.1442-1465.

Spreitzer, G. M. (1997), Toward common ground in defining empowerment, R.W. Woodman and W.A. Pasmore (Eds.), Research in Organizational Change and Development, Greenwich, CT: JAI Press.

Spreitzer, G. M. (2007), Taking Stock: A review of more than twenty years of research on empowerment at work, The Handbook of Organizational Behavior, Sage Publications.

Spreitzer, G.M., Kizilos, M.A. ve Nason, S.W. (1997), A dimensional analysis of the relationship between psychological empowerment and effectiveness, satisfaction and strain, Journal of Management, 23, s.679-704.

Sun, Y. S. ve Jin, N. C. (2009), Do Big Five personality factors affect individual creativity? The moderating role of extrinsic motivation, Social Behavior and Personality, 37 (7), s. 941-956.

Sümer, N., Lajunen, T. ve Özkan, T. (2005), Big five personality traits as the distal predictors of road accident involvement, Underwood, G. (Eds.), Traffic and Transport Psychology, USA: Elsevier Ltd.

Tabachnick, B. G. ve Fidell, L. S. (2001), Using multivariate statistics, Ally and Bacon, MA: Needham Heights.

Tabak, A., Basım, N., Tatar, İ. ve Çetin, F. (2010), İzlenim yönetimi taktiklerinde Beş Faktör Kişilik özelliklerinin rolü: Savunma Sanayinde bir araştırma, Ege Akademik Bakış, 10(2), s.539-557.

Tanoff, G. F. ve Oregon, U. (1999), Job satisfaction and personality: The utility of the Five-Factor Model of personality, Information \& Learning, 60 (4), s.1904-1914.

Taras, V., Kirkman, B. L. ve Steel, P. (2010), Examining the impact of Culture's consequences: A three-decade, multilevel, meta-analytic review of Hofstede's cultural value dimensions, Journal of Applied Psychology, 95 (3), s.405-439.

Templer, K. J. (2012), Five-Factor Model of Personality and Job Satisfaction: The Importance of Agreeableness in a Tight and Collectivistic Asian Society, Applied Psychology: An International Review, 61 (1), s.114-129.

Thomas K. W. ve Velthouse B. A. (1990), Cognitive elements of empowerment: An interpretive model of intrinsic task motivation, Academy of Management Review, 15 (4), s.666-681.

Tınar, M. Y. (1999), Çalışma yaşamı ve kişilik, Mercek Dergisi, 14. Mess Yayınları.

Toker, B. (2007), Demografik değişkenlerin iş tatminine etkileri: İzmir'deki Beş ve Dört Yıldızlı Otellere yönelik bir uygulama, Doğuş Üniversitesi Dergisi, 8 (1), s.92-107.

Tolay, E., Sürgevil, O. ve Topoyan, M. (2012), Akademik çalışma ortamında yapısal ve psikolojik güçlendirmenin duygusal bağlılık ve iş doyumu üzerindeki etkileri, Ege Akademik Bakış, 12(4), s.449-465.

Ulu, í. P. (2007), An investigation of adaptive and maladaptive dimensions of perfectionism in relation to adult attachment and big-five personality traits, Yayınlanmamış Doktora Tezi, Ortadoğu Teknik Üniversitesi, Sosyal Bilimler Enstitüsü, Ankara.

Yürür, S. ve Demir, K. (2011), Örgütsel adalet ve psikolojik güçlendirme: Karşlıklı etkileri üzerine bir araştırma, İktisadi ve İdari Bilimler Fakültesi Dergisi, 16(3), s.311-335.

Wat, D. ve Shaffer, M.A.. (2005), Equity and relationship quality influences on organizational citizenship behaviors: The mediating role of trust in the supervisor and empowerment, Personnel Review, 34 (4), s.406-422.

Watson, D. ve Clark, L. A. (1997). Extraversion and its positive emotional core. R. Hogan, J. A. Johnson, ve S. R. Briggs (Ed.). Handbook of Personality Psychology. San Diego, CA: Academic Press, s.767-793. 
Weiss, D. J., Dawis, R. V., England, G. W. ve Lofquist, L. H. (1967), Manual for the Satisfaction Questionnaire, Minnesota Studies in Vocational Rehabilitation, 22. Minneapolis: University of Minnesota Press.

Winkelmann, L. ve Winkelmann, R. (2008), Personality, work, and satisfaction: evidence from the German SocioEconomic Panel. The Journal of Positive Psychology, 3 (4), s.266-275.

Zimmerman, M. A. (1990), Taking aim on empowerment research: On the distinction between individual and psychological conceptions, American Journal of Community Psychology, 18, s.169-177. 